\title{
Neurotransmitter Receptors of Starburst Amacrine Cells in Rabbit Retinal Slices
}

\author{
Z. Jimmy Zhou and Gordon L. Fain \\ Departments of Physiological Science and Ophthalmology, University of California, Los Angles, California \\ 90024-1527
}

The receptor pharmacology of cholinergic ("starburst") amacrine cells was studied in a newly developed rabbit retinal slice preparation with whole-cell patch clamp. Displaced starburst cells were labeled with the fluorescent dye 4,6-diamidino-2-phenylindole (DAPI), and their dendritic morphology was identified in the slice with Lucifer yellow. Under conditions in which synaptic transmission was blocked by $\mathrm{Cd}^{2+}$, starburst cells responded vigorously to the bath-applied neurotransmitters GABA, glycine, and glutamate. The response to GABA consisted of an inward current and an increase in noise, which could be mimicked by the $\mathrm{GABA}_{\mathrm{A}}$ agonists muscimol and trans-4-aminocrotonic acid (TACA), but not by the $\mathrm{GABA}_{B}$ agonist baclofen or the $\mathrm{GABA}_{c}$ agonist cis-4-aminocrotonic acid (CACA). The GABA-evoked currents were reversibly inhibited by bicuculline and picrotoxin and had a reversal potential close to the chloride equilibrium potential. Noise analysis of GABAactivated whole-cell currents yielded elementary conductance estimates of 12.5 pS. Glycine (30-200 $\mu \mathrm{M})$ also activated a $\mathrm{Cl}^{-}$conductance in starburst cells, which could be completely blocked by strychnine. The non-NMDA agonists kainate (KA, 30-100 $\mu \mathrm{M}$ ) and $\alpha$-amino-3-hydroxy-5-methylisoxazole-4-propionic acid (AMPA, $60 \mu \mathrm{M}$ ) evoked robust responses, which were reversibly blocked by 6-cyano-7-nitroquinoxaline-2,3-dione (CNQX), and which reversed near the equilibrium potential for cations. NMDA coapplied with glycine in salines free of $\mathrm{Cd}^{2+}$ and $\mathrm{Mg}^{2+}$ elicited small but detectable responses. The $I N$ relation of the NMDA-evoked response showed a characteristic “ $J$ '"-shaped region in a saline containing $1 \mathrm{mM} \mathrm{Mg}^{2+}$ and $\mathrm{O} \mathrm{Cd}^{2+}$, indicating that NMDA receptors were present directly on starburst cells. This was consistent with our finding that whole-cell currents evoked by KA and NMDA had different noise characteristics. These results place new constraints on models of starburst cell function and suggest that GABA-mediated inhibition of the starburst cell itself may play an important role in directional selectivity in the retina.

[Key words: mammalian retinal slices, cholinergic amacrine cells, synaptic receptors, GABA, glycine, glutamate, directional selectivity]

\footnotetext{
Received Jan. 17, 1995; revised Mar. 10, 1995; accepted Mar. 14, 1995

We thank Nick Brecha, Ethan Cohen, John Lisman, David Marshak, Stephen Massey, Stephen Mills, and Bruce Yazejian for helpful discussions. We also thank Marianne Cilluffo for technical assistance.

Correspondence should be addressed to Dr. Z. Jimmy Zhou, Department of Physiological Science, 3836 Life Science Building, IJniversity of California, Los Angeles, CA 90024-1527.

Copyright (C) 1995 Society for Neuroscience $0270-6474 / 95 / 155334-12 \$ 05.00 / 0$
}

Cholinergic amacrine cells, also known as starburst amacrines because of their distinctive morphology, exist in the rabbit retina as two mirror-symmetric populations in the inner plexiform layer (IPL), each ramifying in one of two narrow strata (for reviews, see Masland and Tauchi, 1986; Vaney, 1990; Wässle and Boycott, 1991). These cells have radially symmetric dendritic fields, extending as wide as $800 \mu \mathrm{m}$, and their dendritic trees overlap one another as much as 70-fold (Famiglietti, 1983a, 1985; Tauchi and Masland, 1984; Vaney, 1984). Starburst cells receive synaptic input from cone bipolar cells and other amacrine cells (Famiglietti, 1983b, 1991; Brandon, 1987) and make direct output synapses onto ganglion cells (primarily complex ganglion cells including direction-selective types, see Masland and Ames, 1976; Ariel and Daw, 1982; Brandon, 1987; Amthor et al., 1989; Famiglietti, 1991, 1992) and amacrine cells, possibly including starburst cells themselves (Brandon, 1987; Millar and Morgon, 1987; Famiglietti, 1991). Starburst cells have also been shown to contain and release GABA (Brecha et al., 1988; Kosaka, et al., 1988; Vaney and Young, 1988; O'Malley and Masland, 1989), although a light-evoked release of GABA has not been demonstrated (O'Malley and Masland, 1989). Light elicits transient responses from starburst cells, as indicated by intracellular recordings (Bloomfield and Miller, 1986; Bloomfield, 1992) and by measurements of $\mathrm{ACh}$ release from the retina (Masland et al., 1984b).

Cholinergic amacrine cells with similar characteristics have been found in all mammalian species so far examined, suggesting that they are a ubiquitous component of mammalian retinal circuitry, and that they play specific physiological roles that are conserved from species to species (Vaney, 1990; Wässle and Boycott, 1991). It has been proposed that starburst cells may be involved in the production of directional selectivity (e.g., Ariel and Daw, 1982; Masland et al., 1984b; Vaney, 1990) and the regulation of the responsiveness of ganglion cells (Ariel and Daw, 1982). Theoretical models, inspired mainly by the anatomy and synaptology of these cells, have been proposed to describe some of these functions (e.g., Dowling, 1970, 1987; Masland et al., 1984b; Vaney, 1990; Borg-Graham and Grzywacz, 1992). For example, it has been speculated that the coordinated release of both an excitatory ( $\mathrm{ACh}$ ) and an inhibitory neurotransmitter (GABA) may allow starburst cells to create directional selectivity in certain ganglion cell types (Vaney, 1990). It has also been hypothesized that local regions of the starburst dendritic tree form independent subunits, whose release of $\mathrm{ACh}$ may be inhibited by a spatially polarized GABAergic input (Masland et al., 1984b).

The modeling of starburst cell function has so far been based 
on few physiological data. Although the polarized anatomical distribution of the input and output synapses of starburst cells has been examined in detail (Famiglietti, 1983b, 1991; Brandon, 1987), virtually nothing is known about the physiology and pharmacology of these synapses. Thus, it is not even clear whether starburst cells have GABA receptors (Linn and Massey, 1992), much less whether GABA input plays a role in mediating an asymmetric GABAcrgic inhibition (Masland et al., 1984b; Borg-Graham and Grzywacz, 1992). An understanding of starburst cell physiology, especially at the cellular and synaptic lev$\mathrm{el}$, is critical for understanding and modeling the functional role of this interesting amacrine cell type in retinal processing.

In order to study the physiology and pharmacology of these cells in greater detail, we have patch clamped identified starburst amacrine cells in a rabbil retinal slice preparation. Displaced (type b) starburst cells were identified as 4,6,-diamidino-2-phenylindole (DAPI)-accumulating cells (Tauchi and Masland, 1984), and their synaptic receptors were studied under conditions in which synaptic transmission was blocked by $\mathrm{Cd}^{2+}$.

Preliminary reports of this work have been given previously in abstract form (Fain and Zhou, 1993; Zhou and Fain, 1994).

\section{Materials and Methods}

Rabbit retinal slice preparation. Pigmented rabbits were obtained from a local breeder. Approximately $0.5 \mu \mathrm{g}$ of the fluorescent dye 4,6-diamidino-2-phenylindole (DAPI) in 30-50 $\mu \mathrm{l}$ of a $0.9 \% \mathrm{NaCl}$ solution was injected intravitreally with a 30.5 gauge hypodermic needle under light anesthesia with halothane and Alcaine (proparacaine hydrochloride, Alcon Inc., Puerto Rico). One to $2 \mathrm{~d}$ later, the animals were sacrificed with a lethal dose of sodium pentobarbital $(200 \mathrm{mg} / \mathrm{kg}$ ). The eyes were immediately enucleated and hemisected behind the ora serrata, and the vitreous body was removed.

The procedures for preparing mammalian retinal slices were adapted from methods used for preparing amphibian retinal slices (Werblin, 1978; Wu, 1987) and mammalian brain slices (Edwards et al., 1989). In brief, 3 to $5 \mathrm{~mm}$ wide strips of eyecup, typically from areas near the visual streak, were cut and placed on nitrocellulose filter paper (Millipore type HAWP, Bedford, MA) with the ganglion cell layer of the retina facing the paper. The sclera, choroid, and pigment epithelium were then removed, leaving the retina adhering to the filter paper. The retina with filter paper was immediately submerged in cold $\left(4^{\circ} \mathrm{C}\right)$ physiological saline (solution B1, see Table 1). The retina was then sliced at a thickness of $150 \mu \mathrm{m}$ with a tissue slicer (Stoelting, Woodale, IL). The slices were subsequently incubated in Ames medium (Ames and Nesbett, 1981) and equilibrated with $95 \% \mathrm{O}_{2} / 5 \% \mathrm{CO}_{2}$ at room temperature $\left(21-25^{\circ} \mathrm{C}\right)$ for periods of $1-15 \mathrm{hr}$, with no apparent changc with time of the physiological properties of the cells.

Whole-cell patch-clamp recording in retinal slices. At the time of patch-clamp recording, a few slices were transferred to a $600 \mu \mathrm{l}$ recording chamber and held to the bottom of the chamber by two rows of Vaseline at the ends of the slices. The cross-section of the slice was viewed under a $40 \times$ water-immersion objective lens configured for Hoffman modulation contrast (HMC) optics (Modulation Optics, Greenvale, NY) with a fixed-stage upright microscope (Zeiss, Thornwood, NY) equipped with epifluorescence and a $35 \mathrm{~mm}$ camera. Whole-cell patch-clamp recordings (Marty and Neher, 1983) were made with a List EPC-7 patch-clamp amplifier (Eberstadt, Germany). Electrodes of 2-5 $\mathrm{M} \Omega$ resistance (in solutions used for the experiments) were pulled from borosilicate filament glass $(0.86 \mathrm{~mm}$ i.d. and $1.5 \mathrm{~mm}$ o.d.; Sutter Instruments, San Rafael, CA) with a Tlaming-Brown puller (Sutter Instruments). The high resistivity of the borosilicate glass and the thickness of the tubing enabled the electrodes to be used at a satisfactory signal-to-noise ratio without fire polishing or coating. Series resistance, typically between 10 and $15 \mathrm{M} \Omega$ was compensated by $0-50 \%$ with the series resistance compensation circuitry in the patch-clamp amplifier. In nearly all cases, the voltage error due to uncompensated series resistance was $\leq 4.5 \mathrm{mV}(\leq 6 \%)$, since the responses were typically $<300$ $\mathrm{pA}$ at a holding potential of $-70 \mathrm{mV}$. The liquid junction potential was corrected as in Fenwick et al. (1982). Data were low-pass filtered at $0.1-2 \mathrm{kHz}\left(f_{C}\right)$ with an eight-pole Butterworth filter (Frequency Device
Table 1. Compositions of the bath solutions (B1-B4) and of the pipette solutions (P1-P3) used in the study of effects of ligands on starburst amacrine cells

\begin{tabular}{|c|c|c|c|c|c|c|c|}
\hline & $\mathrm{B} 1$ & B2 & B3 & B4 & PI & $\mathrm{P} 2$ & P3 \\
\hline $\mathrm{NaCl}$ & 135 & 137 & 141.7 & 100 & & & \\
\hline $\mathrm{KCl}$ & 4.3 & 4.3 & 4.3 & 4.3 & & & \\
\hline $\mathrm{CsCl}$ & & & & & 38.4 & 30 & 90 \\
\hline $\mathrm{CsMeSO}_{4}$ & & & & & 75.6 & 75 & \\
\hline $\mathrm{CaCl}_{2}$ & & 1.7 & 1.7 & & 0.5 & 0.5 & 0.5 \\
\hline $\mathrm{MgCl}_{2}$ & 1.2 & & & & 2 & 2 & 2 \\
\hline $\mathrm{BaCl}_{2}$ & & & & 10 & & & \\
\hline TEA-Cl & & & & 20 & & 15 & 30 \\
\hline $\operatorname{ATP}(2 \mathrm{Na})$ & & & & & 3 & 2 & 2 \\
\hline $\operatorname{GTP}(3 \mathrm{Na})$ & & & & & 0.5 & 0.5 & 0.5 \\
\hline EGTA & & & & & 5 & 5 & 5 \\
\hline HEPES & 10 & 10 & 10 & 10 & 10 & 10 & 10 \\
\hline $\mathrm{NaHCO}_{3}$ & 2 & & & & & & \\
\hline Glucose & 15 & 15 & 15 & 1 & & & \\
\hline Glutamine & 0.5 & & & & & & \\
\hline L-Ascorbic acid & 0.5 & & & & 2 & 2 & 2 \\
\hline $4-\mathrm{AP}$ & & & 5 & 5 & & & \\
\hline $\mathrm{NaOH}$ & 5.0 & 4.7 & & & & & \\
\hline $\mathrm{HCl}$ & & & 0.7 & 0.6 & & & \\
\hline $\mathrm{pH}$ & 7.4 & 7.4 & 7.4 & 7.4 & 7.2 & 7.2 & 7.2 \\
\hline
\end{tabular}

All numbers are in millimolar concentrations.

Model 901, Haverhill, MA) and stored on a Sony VCR (Model SLHF750, Philadelphia, PA) through a pulse code modulator (PCM, Sony Model 501, $44 \mathrm{kHz}$ sampling rate) or on an IBM-compatible 80486 computer through an Axon Instruments data-acquisition interface (TL1/DMA with pCLAMP software, Axon Instruments Inc., Burlingame, CA). Data analysis was done with pCLAMP and ORIGIN software (MicroCal Software Inc.; Northampton, MA).

Whole-cell $I / V$ relationships were obtained by ramping the command potential $(40 \mathrm{mV} / \mathrm{sec})$ from $-75 \mathrm{mV}$ to $+45 \mathrm{mV}$, or vice versa. 'The $l /$ $V$ curves for drug-induced responses were constructed by subtracting the averages of two to four ramps in the absence of drugs from the averages of two to four ramps in the presence of drugs. Estimates of single-channel conductances were derived from analysis of the wholecell current noise recorded under voltage clamp (Neher and Stevens, 1977). For noise analysis, prerecorded whole-cell currents (filtered at an $f_{C}$ of $2 \mathrm{kHz}$, Butterworth filter) were played back from the VCR, refiltered at $500 \mathrm{~Hz}\left(f_{C}\right.$, Butterworth filter), and digitized at $1.5 \mathrm{kHz}$ with pCLAMP. Segments of the digitized data, each of which contained 512 digitized data points, were collected sequentially. Each segment was analyzed with okigin software to generate values for the inean current amplitude $(\vec{l})$ and the variance $\left(\delta^{2}\right)$, which were subsequently used to make $\delta^{2}-\bar{t}$ plots. Linear regression was done with ORIGIN software (Marquardt-Levenberg algorithm).

Drug application and solutions. During electrophysiological recording, retinal slices were continuously superfused $(2 \mathrm{ml} / \mathrm{min})$ with either bicarbonate-based Ames medium or HEPES-based salines (see Table 1). Drugs were dissolved in HEPES-based saline and bath applied to the slice via the superfusion system. $\mathrm{CdCl}_{2}(1 \mathrm{~mm})$ was usually added to the extracellular medium to block synaptic transmission, except in some experiments for which the effects of NMDA were studied. The intracellular (pipcttc) solutions (sec Table 1) contained 0.1-1\% Lucifer yellow, which rapidly filled the cell after breaking through to form a whole-cell recording. The dendritic morphology of Lucifer yellowstained cells was examined and photographed with epifluorescence al the end of each recording.

The drugs $\alpha$-amino-3-hydroxy-5-methylisoxazole-4-propionic acid (AMPA) and 6-cyano-7-nitroquinoxaline-2,3-dione (CNQX) were obtained from Research Biochemical Incorporated (Natick, MA); trans-4aminocrotonic acid (TACA) and cis-4-aminocrotonic acid (CACA) were obtained from Tocris Cookson (Bristol, UK). All other drugs were purchased from Sigma Chemicals (St. Louis, MO), Most drugs were 
frozen $\left(-20^{\circ} \mathrm{C}\right)$ in small aliquots in $10-50 \mathrm{~mm}$ stock solutions. These aliquots were thawed and added to the extracellular solutions on the day of the experiment. Bicuculline methiodide (BIC) and picrotoxin (PTX) were dissolved freshly on the day of the experiment.

\section{Results}

\section{Identification of starburst cells in the rabbit retinal slice}

The layered organization of the rabbit retina could be clearly visualized in the retinal slice under a $40 \times$ water-immersion HMC objective lens, and individual cells near the surface of the slice were easily recognized (Fig. 1A). With epifluorescence, cells stained by intraocularly injected DAPI formed two bands in the slice: one in the inner nuclear layer (INL) and the other in the ganglion cell layer (GCL, Fig. 1B). As previously described (Masland et al., 1984a), the most brightly stained cell population in the GCL consisted of displaced cholinergic amacrine cells. They had round or slightly oval cell bodies, 7-10 $\mu \mathrm{m}$ in diameter, and located near the border between GCL and IPL (Fig. $1 A, B$ ). The nuclei of DAPI-labeled displaced starburst cells often had a cupped appearance, occupying a large part of the cellular volume, as previously reported (Masland et al., 1984a; Tauchi and Masland, 1984). Because DAPI labels several different cell types in the INL (Masland et al., 1984a), our recordings were made exclusively from DAPI-labeled, displaced starburst amacrine cells in the GCL.

Cells with bright DAPI staining and smooth cell surfaces, indicative of healthy cells, were selected for patch-clamp recording (see Fig. 1). In nearly all cases, the cells from which we recorded had a distinctive, unistratified dendritic morphology (Fig. 1C), characteristic of starburst amacrine cells (Famiglietti, 1983a; Tauchi and Masland, 1984, 1985; Vaney, 1984). The dendrites of these cells were thin, often varicose, and always ramifying narrowly in sublamina 4 of the IPL (Fig. $1 C$ ). We did not observe any apparent detrimental effects of DAPI or Lucifer yellow on the membrane currents recorded under our experimental conditions.

Results reported in the following were obtained from 131 displaced starburst amacrine cells identified based on their somal size, DAPI staining, and dendritic morphology. Cells having bright DAPI staining but few Lucifer yellow-filled dendrites were excluded from the analysis. Cells recorded in Ames medium had a resting membrane potential (measured as the zero current potential immediately after the formation of the wholecell recording) of from -30 to $-75 \mathrm{mV}$.

\section{Responses of starburst cells to exogenously applied ligands}

In order to characterize neurotransmitter receptors present directly on the starburst amacrine cell membrane, we tested the effects of various amino acids as well as cholinergic agonists and antagonists in the slice under conditions in which synaptic transmission was blocked with $1 \mathrm{mM} \mathrm{Cd}^{2+}$. Cells were voltage clamped at $-70 \mathrm{mV}$, and drugs were bath applied. Because distal starburst dendrites may have been poorly voltage clamped and may also have been truncated during slicing, our results may be biased toward receptors in the proximal regions of the cell.

As shown in Table 2, displaced starburst cells responded consistently to bath-applied inhibitory amino acids-GABA, muscimol (MUSC), TATA, and glycine (GLY); as well as the excitatory amino acids glutamate (GLU), kainic acid (KA), AMPA, and NMDA. Figure 2 shows typical whole-cell current responses of two starburst amacrine cells to various amino acid agonists at a holding potential $\left(V_{h}\right)$ of $-70 \mathrm{mV}$ in a $\mathrm{Mg}^{2+}$-free saline containing $1 \mathrm{mM} \mathrm{Cd}^{2+}$. The responses to GABA and GLY
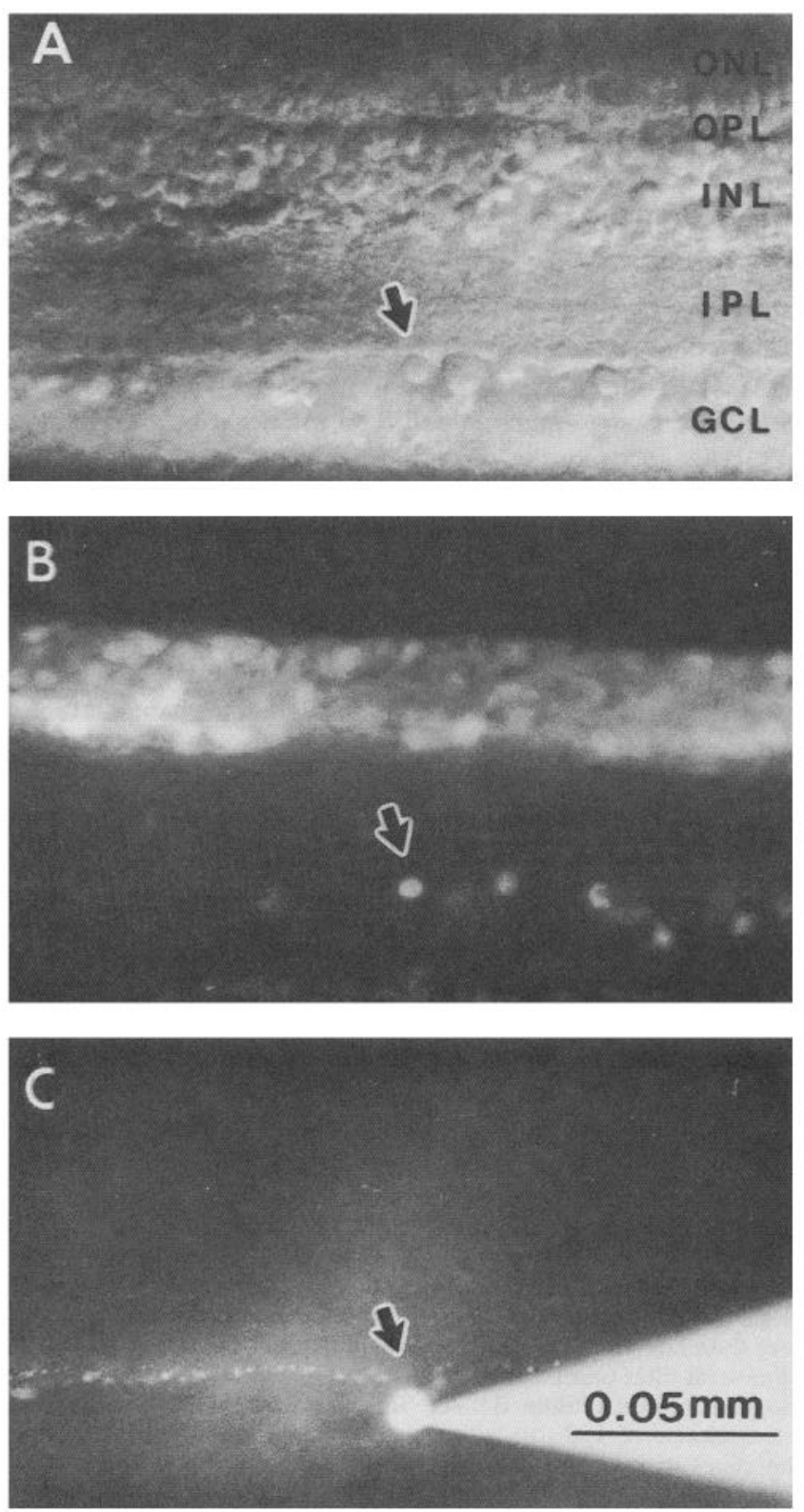

Figure 1. Photomicrographs of the rabbit retinal slice. A, A $150 \mu \mathrm{m}$ thick slice photographed with Hoffman modulation contrast optics with a $40 \times$ water-immersion objective lens, showing the layered organization of the rabbit retina ( $G C L$, ganglion cell layer; $I P L$, inner plexiform layer; $I N L$, inner nuclear layer; $O P L$, outer plexiform layer; and $O N L$, outer nuclear layer). The photoreceptor layer is not shown. $B$, Epifluorescence photomicrograph of the same slice as in $A$, showing the pattern of dye staining $1 \mathrm{~d}$ after an intravitreal injection of DAPI. $C$. Fluorescence micrograph of the dendritic morphology of the starburst cell after whole-cell patch-clamp with a Lucifer yellow-filled pipette. $A r$ rows in $A-C$ indicate same displaced starburst amacrine cell.

were desensitizing and were accompanied by an increase in current noise. KA-induced currents, on the other hand, were rather sustained and less noisy than GABA- and GLY-evoked currents, perhaps due, in part, to smaller single channel conductances of non-NMDA receptors (see below). AMPA and NMDA also evoked inward current responses, though the responses to NMDA were very small, presumably due, in part, to the block of NMDA channels by $\mathrm{Cd}^{2+}$ (see below). The amplitude of the 
Table 2. Number of starburst amacrine cells responding to various agonists

\begin{tabular}{llllllllllll} 
Drug & GABA & MUSC & TACA CACA & BAC & GLY & TAU & GLU $^{a}$ & KA & AMPA & NMDA $^{a}$ \\
\hline$\mu \mathrm{M}$ & $30-200$ & 100 & 100 & $100-300$ & 100 & $30-200$ & 100 & 200 & $15-50$ & 60 & $100-200$ \\
$n_{,}\left(n_{t}\right)$ & $44(45)$ & $4(4)$ & $2(2)$ & $5(8)$ & $0(2)$ & $20(21)$ & $1(4)$ & $13(13)$ & $30(32)$ & $5(5)$ & $25(28)$
\end{tabular}

$n_{r}$, number of cells having detectable responses; $n_{r}$, number of cells tested. Cells were recorded under voltage clamp $\left(V_{h}=-70 \mathrm{mV}\right)$ in solutions shown in Table 1 . All drugs were bath applied in extracellular solutions containing 1 $\mathrm{mM} \mathrm{CdCl}$, except for $\mathrm{NMDA}$, which was tested in salines free of $\mathrm{Cd}^{2+}, \mathrm{Mg}^{2+}, \mathrm{Ba}^{2+}$, and $\mathrm{TEA}$.

"Coapplied with $1 \mu \mathrm{M}$ GLY.

responses to various agonists varied from cell to cell in the range from tens to hundreds of $\mathrm{pA}$ at $V_{h}=-70 \mathrm{mV}$, but the waveform of the responses for each agonist was distinctive and similar in all cells tested.

\section{$G A B A$ receptors}

Effects of $G A B A$ receptor agonists. The vertebrate retina has been shown to express a number of $\mathrm{GAB} \Lambda$ receptor subtypes, including $\mathrm{GABA}_{\mathrm{A}}$ (for a review, see Yazulla, 1986; Massey and Redburn, 1987), GABA (e.g., Maguire et al., 1989a,b; Slaugh-

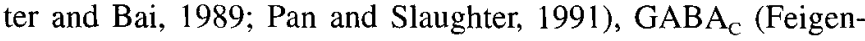
span et al., 1993; Qian and Dowling, 1993; Dong et al., 1994; Lukasiewicz et al., 1994), and $\mathrm{GABA}_{\mathrm{B} / \mathrm{C}}$-like receptors (Matthews et al., 1994). We first studied the pharmacology of GABA receptors on starburst cells by comparing the effects of various GABA receptor agonists. GABA, the natural agonist, always elicited a desensitizing current response at a $V_{h}$ of $-70 \mathrm{mV}$ (Fig. $3 A$ ). The current response rose to a peak amplitude within 10 $15 \mathrm{sec}$ (presumably reflecting the time course of bath perfusion) and then declined during maintained application of GABA with a half-decay time (defined as the time required for a response to decay to its half-maximal amplitude) of about $20-30 \mathrm{sec}$,

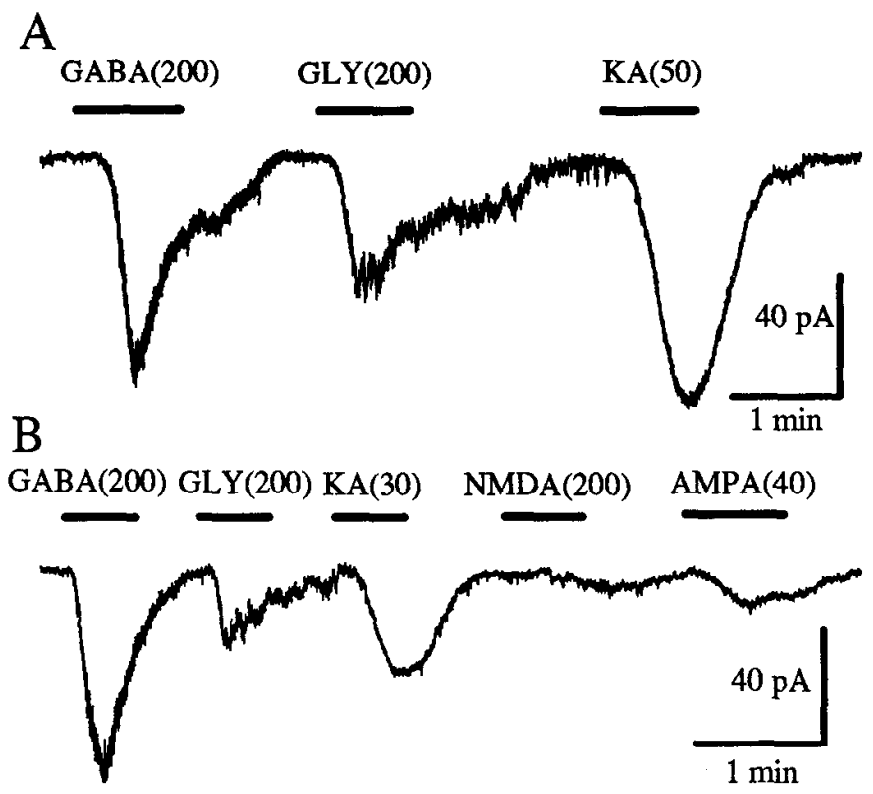

Figure 2. Whole-cell current responses of starburst amacrine cells to bath-applied amino acid agonists GABA, GLY, KA, AMPA, and NMDA + GLY $(1 \mu \mathrm{M})$, at a holding potential $\left(\mathrm{V}_{h}\right)$ of $-70 \mathrm{mV}$, in solutions P1 and $\mathrm{B} 2$ (supplemented with $1 \mathrm{mM} \mathrm{Cd}^{2+}$, see Table 1). Numbers shown in parentheses indicate the concentration of drug in $\mu \mathrm{M}$, and horizontal bars give the timing of drug application. Recordings in $A$ and $B$ are from different cells. though the response rarely declined completely to the baseline level even after $1 \mathrm{~min}$ of GABA application (Fig. $3 A$ ). The response to GABA $(100 \mu \mathrm{M})$ under voltage clamp could be mimicked by the $\mathrm{GABA}_{\mathrm{A}}$-receptor agonist MUSC $(100 \mu \mathrm{M})$, but not by the $\mathrm{GABA}_{\mathrm{B}}$-receptor agonist baclofen $(\mathrm{BAC}, 100 \mu \mathrm{M})$ or by CACA $(100 \mu \mathrm{M})$, a preferred agonist for $\mathrm{GABA}_{\mathrm{C}}$ receptors (Fig. $3 B$ ). CACA, at a concentration of $100 \mu \mathrm{M}$, sometimes induced an increase in the noise level of the holding current without eliciting an appreciable inward current. Increasing the concentration of CACA to $300 \mu \mathrm{M}$, however, could evoke a detectable but still small response in starburst cells (Fig. $3 C$ ). On the other hand, the trans isomer of crotonic acid (TACA, $100 \mu \mathrm{M}$ ), which is considered a $\mathrm{GABA}_{\mathrm{A}}$ agonist (Johnston et al., 1975), mimicked the effects of GABA and MUSC, and was slightly more effective than GABA at the same agonist concentration of 100 $\mu \mathrm{M}$ (Fig. 3D).

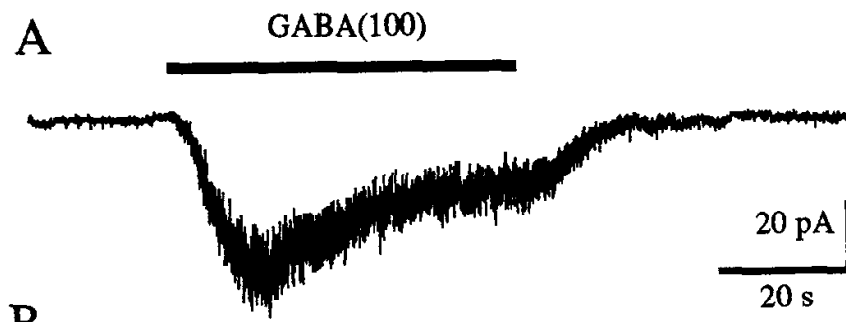

B

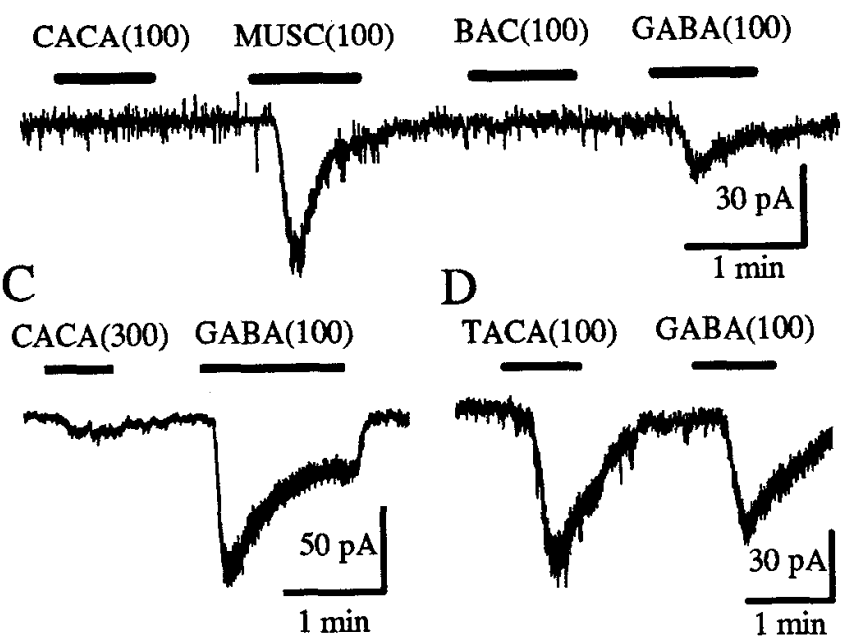

Figure 3. Effects of GABA receptor agonists. A, Whole-cell current response to GABA. $B$, The effect of GABA was mimicked by MUSC but not by $100 \mu \mathrm{M}$ CACA or BAC. $C$, Increasing the concentration of CACA to $300 \mu \mathrm{M}$ resulted in a very small response. $D$, TACA mimicked the effects of GABA. All recordings were made at a $V_{h}=-70$ $\mathrm{mV}$, in bath solution $\mathrm{B} 4+1 \mathrm{mM} \mathrm{Cd}^{2+}$, and pipette solution P2 (see Table 1). Numbers shown in parentheses indicate the concentration of drug in $\mu \mathrm{M}$. 
Antagonistic effects on GABA receptors. The effects of the GABA receptor antagonists bicuculline (BIC) and picrotoxin (PTX) were tested by coapplying them with agonists. As shown in Figure 4, responses to $100 \mu \mathrm{M} \mathrm{GABA}(n=3)$ and TACA ( $n$ $=1$ ) were reversibly blocked by BIC (20-30 $\mu \mathrm{M})$, suggesting that the response of starburst cells to GABA was mediated predominantly by $\mathrm{GABA}_{\mathrm{A}}$-receptors. However, BIC, at this concentration, did not completely inhibit the response to $100 \mu \mathrm{M}$ GABA; a small and more sustained component of the response persisted in the presence of $30 \mu \mathrm{M}$ BIC (Fig. 4A). In order to determine whether there was a BIC-insensitive, nondesensitizing, $\mathrm{GABA}_{\mathrm{C}}$-like componcnt in the GABA rcsponsc, such as that shown in a subset of retinal horizontal, bipolar, and ganglion cells (Feigenspan et al., 1993; Qian and Dowling, 1993; Dong and Werblin, 1994; Lukasiewicz et al., 1994), we tested the effects of BIC at a higher concentration $(300 \mu \mathrm{M})$. Figure $4 \mathrm{C}$ shows that $300 \mu \mathrm{M}$ BIC completely blocked the effects of 100 $\mu \mathrm{M}$ GABA $(n=4)$, suggesting that there were few, if any, BICresistant $\mathrm{GABA}$ receptor channels in starburst amacrine cells.

We also studied the effects of another potent GABA receptorchanncl blocker picrotoxin (PTX). Coapplication of $30 \mu \mathrm{M}$ PTX with $100 \mu \mathrm{M}$ GABA did not block the GABA response immediately after the drugs were applied, since the peak amplitude of the response to GABA was not changed in the presence of PTX (Fig. 4D). However, the decay rate of the response was greatly increased by PTX (Fig. $4 D$ ), suggesting that the blocking effect of PTX developed with time. When the same concentrations of PTX and GABA were applied together for a second time, most of the response, including the peak response, was greatly reduced (Fig. $4 D$ ). Increasing the concentration of PTX to $300 \mu \mathrm{M}$ in a different cell produced both a large reduction in the peak response to $100 \mu \mathrm{M}$ GABA and a faster decay of current (Fig. $4 E$ ). The recovery from PTX block was gradual and appeared to have been facilitated by further activation of receptors by the agonist (Fig. $4 E$ ), although a more detailed investigation would be required to determine the exact mechanism by which PIX blocks GABA responses in starburst cells. PTX is generally thought to be a noncompetitive receptor channel blocker (Ticku et al., 1978; ffrench-Constant et al., 1993).

Ionic selectivity and current-voltage relationship. The current-voltage relation of the GABA-activated response was recorded in solutions having asymmetric $\mathrm{Cl}^{-}$concentrations (solutions B4 and P2, Table 1), with equilibrium potentials of -27 $\mathrm{mV}$ for $\mathrm{Cl}^{-}\left(E_{\mathrm{Cl}}\right)$ and $+0.5 \mathrm{mV}$ for cations $\left(E_{\mathrm{cat}}\right)$. Whole-cell currents in response to voltage ramps from $-73 \mathrm{mV}$ to $+42 \mathrm{mV}$ (Fig. 5A) were recorded under voltage clamp (see Materials and Methods). The $I / V$ relation for the response to $100 \mu \mathrm{M}$ GABA was outwardly rectifying $(n=3)$, due, in part, to Goldman rectification (Johnston and $\mathrm{Wu}, 1995$ ) caused by the asymmetric concentration of $\mathrm{Cl}^{-}$in the bath and pipette solutions. The reversal potential for GABA-activated currents was $-26 \mathrm{mV} \pm$ $4 \mathrm{mV}$ (mean $\pm \mathrm{SD}, n=3$ ), which was near $E_{\mathrm{Cl}}$ but far from $E_{\text {cat }}$, confirming the $\mathrm{Cl}^{-}$-selectivity of $\mathrm{GABA}_{\mathrm{A}}$ receptors.

The increase in noise seen accompanying the GABA-evoked whole-cell currents (Figs. 1-6) was used to estimate the singlechannel chord conductance of the GABA-activated channels. As shown in Figure $6 A$, GABA $(100 \mu \mathrm{M})$ was slowly bath applied to the cell, eliciting a slowly rising response accompanied by a gradual increase in current noise. The estimated elementary conductance $(\gamma)$ was calculated from the equation $\gamma=\delta^{2} / \bar{l}\left(V_{h}-\right.$ $V_{\text {ef }}$ ), where $\delta^{2}$ is the current variance, $\bar{l}$ is the mean current, $V_{h}$ is the holding potential, and $V_{\mathrm{eq}}$ is the reversal potential of the

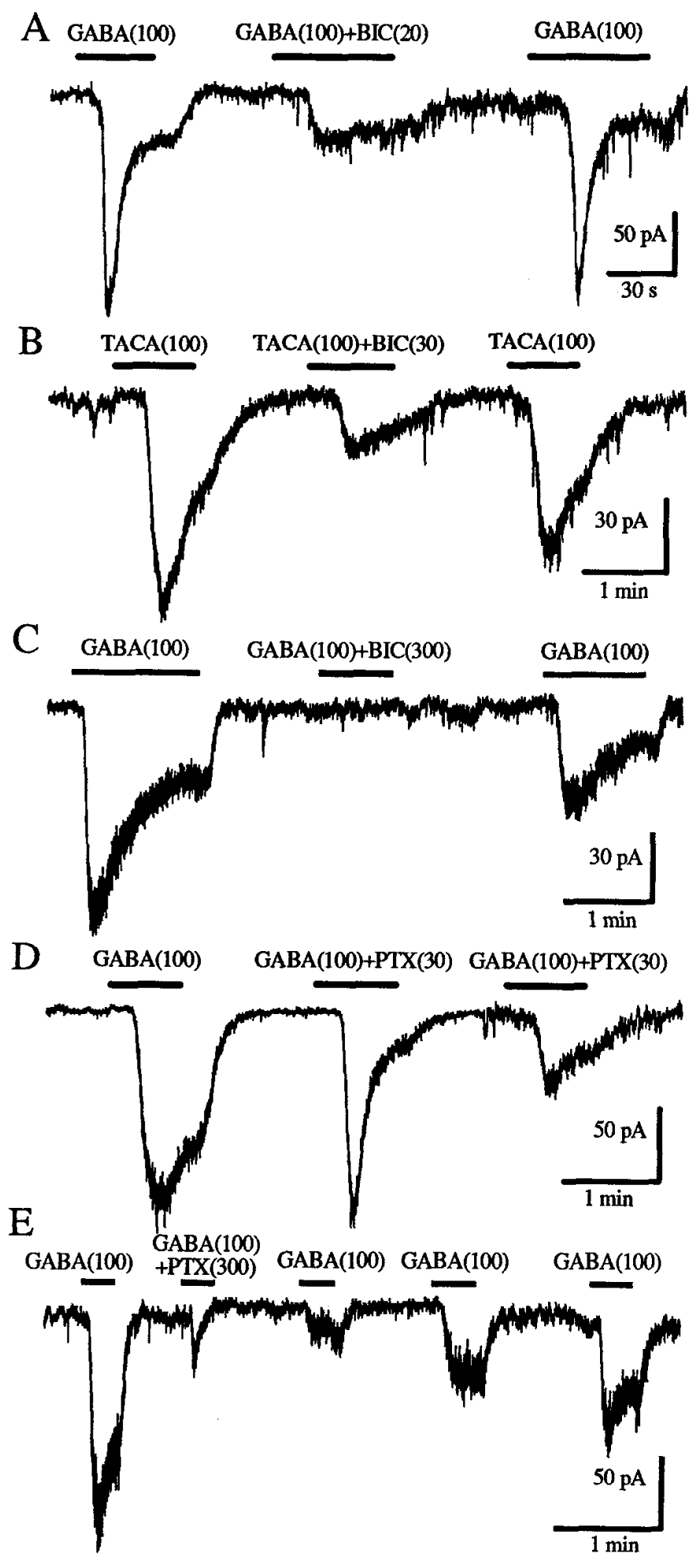

Figure 4. Antagonistic effects of bicuculline (BIC) and picrotoxin $(P T X)$. BIC, at concentrations of 20 and $30 \mu \mathrm{M}$, partially and reversibly blocked the responses of starburst cells to $100 \mu \mathrm{M} \mathrm{GABA}(A)$ and 100 $\mu \mathrm{M}$ TACA $(B) . C$, BIC $(300 \mu \mathrm{M})$ reversibly and completely blocked the effects of $100 \mu \mathrm{M}$ GABA. $D$ and $E$, Antagonistic effects of PTX on GABA-evoked responses (see Results for details). Pipette solution P2 and bath solution B4 with $1 \mathrm{mM} \mathrm{Cd}^{2+}$ (see Table 1). Records in $A E$ are all from different cells. Numbers shown in parentheses indicate the concentration of drug in $\mu \mathrm{M}$. $V_{h}=-70 \mathrm{mV}$. 

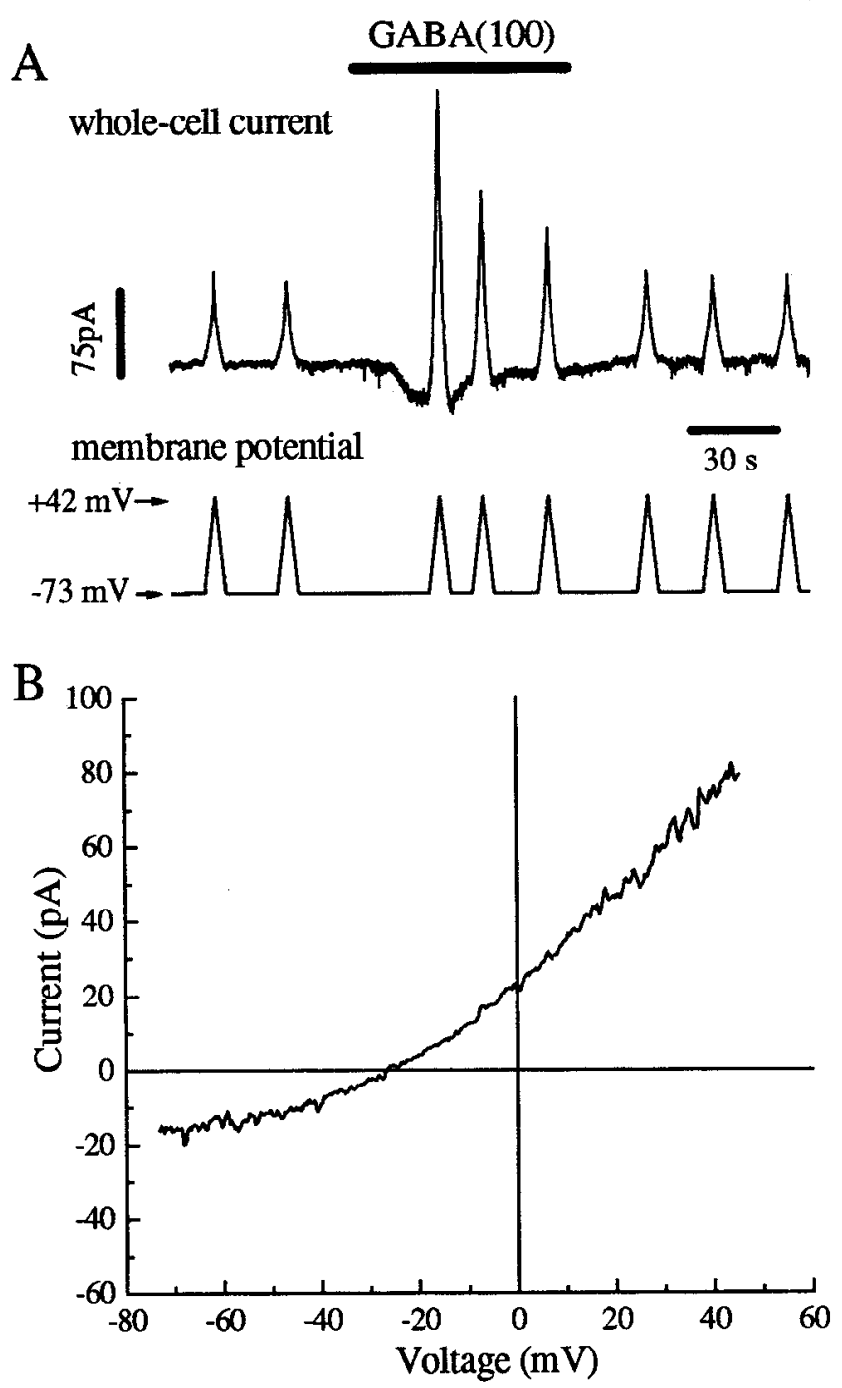

Figure 5. Current-voltage relation of GABA-evoked currents. A, Whole-cell currents (upper trace) in response to voltage ramps $(25 \mathrm{mV} /$ $\mathrm{sec}$, lower trace) from a holding potential of $-73 \mathrm{mV}$. B. The average of the five ramps recorded in the absence of GABA was subtracted from the average of the three ramps recorded during the application of GABA. Pipette solution P2 and bath solution B4 with $1 \mathrm{mM} \mathrm{Cd}^{2+}\left(E_{\mathrm{O}}\right.$ $=-27 \mathrm{mV}$, see Table 1). The number shown in parentheses indicates the concentration of drug in $\mu \mathrm{M}$.

response (Neher and Stevens, 1977). The whole-cell current data were sampled at $1.5 \mathrm{kHz}$ before and during the application of GABA to generate the plot of $\delta^{2}$ versus $\bar{l}$ (Fig. $6 B$ ). Each data point in Figure $6 B$ represents the current variance $\left(\delta^{2}\right)$ corresponding to a mean current amplitude $(\vec{l})$ averaged over a period of $341 \mathrm{msec}$ (see Materials and Methods), during which the receptors were treated as being in a quasi-steady state, since the agonist was applied very slowly. Only the initial part of the response, presumably evoked by low concentrations of GABA, was used for the $\delta^{2}-\bar{l}$ plot and analyzed with linear regression to yield the slope of the plot. From the three cells recorded at a $V_{k}$ of $-70 \mathrm{mV}$ in the bath solution B2 and the pipette solution P3 (see Table $1, E_{\mathrm{Cl}}=-4 \mathrm{mV}$ ), the average value for the elementary conductance $(\gamma)$ was $12.5 \pm 0.7 \mathrm{pS}$ (mean $\pm \mathrm{SD}$ ), similar to values estimated from noise analysis of GABA-evoked currents in other cells (e.g., Cull-Candy and Ogden, 1985; Inenaga and Mason, 1987; Ishida and Cohen, 1988) and close to one of
A

\section{GABA}
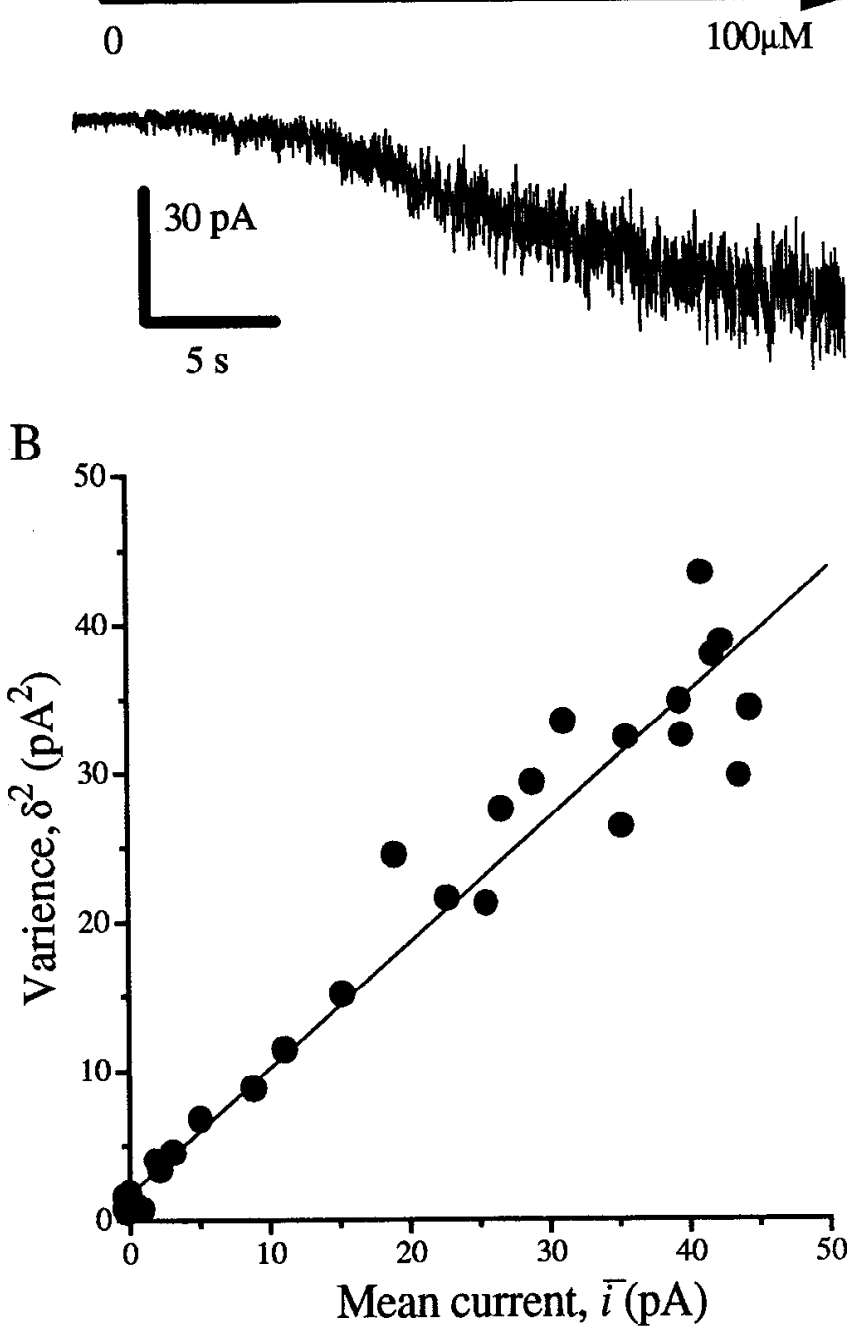

Figure 6. Estimate from whole-cell current noise of the elementary amplitude of the GABA-activated conductance. $A$, The whole-cell current response to bath application of GABA. $B$, variance as a function of current mean (see Materials and Methods). The line drawn through the points is a linear regression $(r=0.99)$, and division of its slope by the driving force for the response $(66 \mathrm{mV}$ in pipette solution $\mathrm{P} 3$ and bath solution $\mathrm{B} 2+1 \mathrm{mM} \mathrm{CdCl}_{2}$, see Results) yields a single-channel conductance estimate for this cell of $13.1 \mathrm{pS}$.

the conductance states of GABA receptor channels found by single-channel recordings (e.g., Hamill et al., 1983, Bormann and Clapham, 1985; Cohen et al., 1989; MacDonald et al., 1989).

\section{Glycine receptors}

Almost all starburst cells tested (Table 2) responded to bathapplied GLY (50-200 $\mu \mathrm{M})$ with an inward, desensitizing current at a $V_{h}$ of $-70 \mathrm{mV}$. The responses to $100 \mu \mathrm{M}$ GLY could be nearly completely blocked by the glycine receptor antagonist strychnine (STRYCH, $3 \mu \mathrm{M}, n=3$ ). A slightly lower concentration of STRYCH $(1 \mu \mathrm{M}$, Fig. $7 A)$ blocked the current response to GLY $(100 \mu \mathrm{M})$ by $79 \pm 14 \%$ (mean $\pm \mathrm{SD}, n=4)$, and the recovery of glycine response after the wash-out of strychnine was often incomplete. The current-voltage relation of GLY-ac- 
tivated responses was slightly outward rectifying (Fig. $7 B$ ). The reversal potential of GLY-evoked currents also followed closely the equilibrium potential for $\mathrm{Cl}^{-}$. When the intracellular $\mathrm{Cl}^{-}$ concentration was reduced from $125 \mathrm{mM}\left(E_{\mathrm{Cl}}=-4 \mathrm{mV}\right.$, pipette solution P3 and bath solution B2) to $50 \mathrm{~mm}\left(E_{\mathrm{Cl}}=-27 \mathrm{mV}\right.$, pipette solution $\mathrm{P} 2$ and bath solution B2), the reversal potential shifted from $-1 \pm 2 \mathrm{mV}(n=2)$ to $-30 \pm 4 \mathrm{mV}(n=2)$. Thus, the rcsponse of starburst amacrine cells to GLY was mediated by strychnine-sensitive glycine receptor channels like those previously described for neurons in spinal cord, CNS, and retina (e.g., Bormann et al., 1987; Akaike and Kaneda, 1989; Zhou et al., 1993). On the other hand, bath application of taurine $(100 \mu \mathrm{M})$ elicited only a very small response from one of the four cells tested and was without effect in the remaining three cells.

\section{Excitatory amino acid receptors}

Application of GLU (200 $\mu \mathrm{M}$, together with $1 \mu \mathrm{M}$ GLY) in the presence of $1 \mathrm{mM} \mathrm{Cd}^{2+}$ elicited an inward, desensitizing current (Fig. 8A). In order to characterize the receptors mediating the responses to GLU, we studied the effects of various agonists and antagonists of ionotropic glutamate receptors.

Non-NMDA receptors. Starburst cells responded consistently to the non-NMDA receptor agonists KA (15-50 $\mu \mathrm{M})$ and AMPA $(60 \mu \mathrm{M})$. The responses to KA were sustained (Figs. 2, 8) during maintained bath application of agonists, whereas those to AMPA were desensitizing (Figs. 2, 9). Both KA- and AMPA-evoked responses could be reversibly blocked by the quinoxalines CNQX and DNQX, though the block was not complete at the concentrations we used (10-25 $\mu \mathrm{M})$. Figure $8 B$ shows the effect of $25 \mu \mathrm{M}$ CNQX on responses evoked by $25 \mu \mathrm{M} \mathrm{KA}$. At this concentration, CNQX reduced the amplitude of responses to KA by $69 \pm 17 \%$ (mean $\pm \mathrm{SD}, n=5$ ). CNQX $(25 \mu \mathrm{M}$ ) also blocked the response to AMPA ( $60 \mu \mathrm{M}$, data not shown). The current-voltage relation of KA-evoked responses (Fig. 8C) was nearly linear or somewhat outwardly rectifying in solutions containing nearly symmetric cations and asymmetric $\mathrm{Cl}^{-}$(B2 and $\mathrm{P} 2$, see Table 1). No evidence of inward rectification was observed. The reversal potential of KA-evoked currents was 0.6 $\pm 4 \mathrm{mV}$ (mean $\pm \mathrm{SD}, n=3$ ), close to the equilibrium potential for cations $(6 \mathrm{mV})$ and away from the equilibrium potential for anions $\left(E_{\mathrm{Cl}}=-27 \mathrm{mV}\right)$, demonstrating that the receptors were, indeed, cation selective.

NMDA receptors. As shown in Figure 9A, application of NMDA together with $1 \mu \mathrm{M}$ GLY in a saline free of $\mathrm{Mg}^{2+}$ and $\mathrm{Cd}^{2+}$ evoked a small, inward current. Most of the cells tested under this condition responded to NMDA (Table 2), but the size of the response was quite variable $(10-100 \mathrm{pA})$ and was usually small. An increase in current noise was often seen to accompany the response. When $1 \mathrm{mM} \mathrm{Cd}^{2+}$ was added to the $\mathrm{Mg}^{2+}$-free saline to block synaptic transmission, the response to NMDA disappeared, while the response to AMPA persisted (Fig. 9A). This inhibition of the NMDA response by $\mathrm{Cd}^{2+}$ may be explained by the following two possibilities: (1) NMDA receptors on the starburst cells were blocked by $\mathrm{Cd}^{2+}$, presumably at the $\mathrm{Zn}^{2+}$ binding site of the receptors (Mayer and Westbrook, 1987; Ascher and Nowak, 1988b; Mayer et al., 1989); and (2) the effect of NMDA on starburst cells was indirect (i.e., mediated by NMDA receptors present on neurons presynaptic to starburst cells) and was therefore abolished when synaptic transmission was blocked by $\mathrm{Cd}^{2+}$. In the following, we provide two experiments that suggest that at least some of the response to NMDA
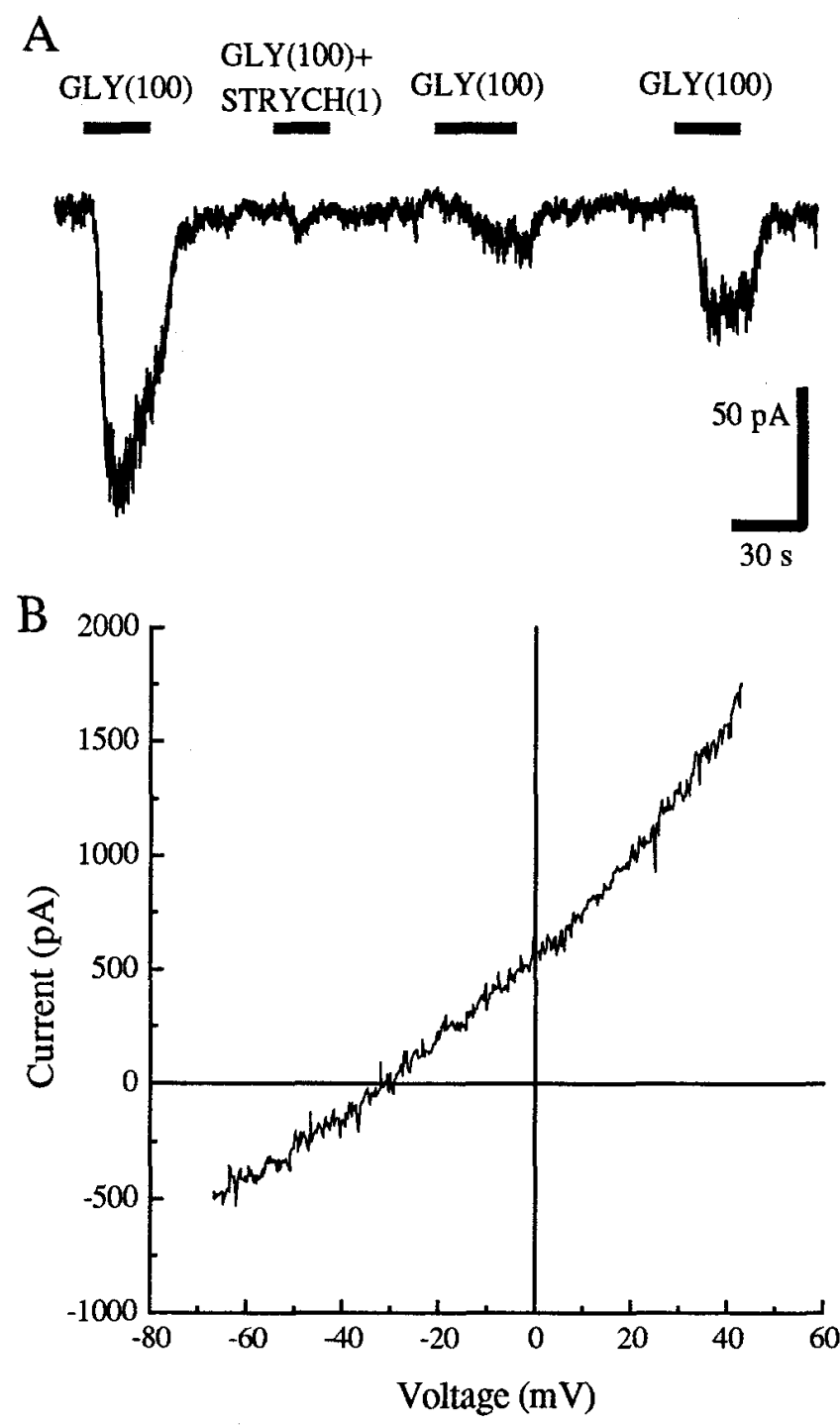

Figure 7. Glycine-evoked responses in starburst cells. A, Response to GLY was blocked by STRYCH $(1 \mu \mathrm{M})$ and partially recovered after a gradual washout of antagonist $\left(V_{h}=-70 \mathrm{mV}\right)$. Pipette solution $\mathrm{P} 2$ and bath solution $\mathrm{B} 4+1 \mathrm{mM} \mathrm{Cd}^{2+}$ (see Table 1). Numbers shown in parentheses indicate the concentration of drug in $\mu \mathrm{M}$. $B$, The $I / N$ relation for GLY-evoked responses is constructed from the average current response during voltage ramps (see Fig. 5 caption) in pipette solution $\mathbf{P} 2$ and bath solution $\mathrm{B} 2+1 \mathrm{mM} \mathrm{CdCl}_{2}\left(E_{\mathrm{Cl}}=-27\right.$, see Table 1). Records in $A$ and $B$ are from different cells.

recorded in the absence of $\mathrm{Cd}^{2+}$ was due to activation of NMDA receptors directly present on starburst amacrine cells.

Figure $9 B$ shows $I / V$ curves of responses evoked by NMDA (200 $\mu \mathrm{M}$, coapplied with $1 \mu \mathrm{M}$ GLY) in a $\mathrm{Cd}^{2+}$-free saline, first in the absence and then in the presence of $1 \mathrm{mM} \mathrm{Mg}^{2+}$. Addition of $1 \mathrm{mM} \mathrm{Mg}{ }^{2+}$ resulted in a "J-shaped" region in the $I / V$ curve, reflecting presumably the voltage-dependent block of NMDA channels by $\mathrm{Mg}^{2+}$ (Mayer et al., 1984; Nowak et al., 1984). This characteristic, "J"-shaped voltage dependence in the presence of $\mathrm{Mg}^{2+}$, which has been found only with NMDA receptors and not with other known neurotransmitter receptors, was strong evidence that the action of NMDA was directly on the starburst cell, since only the starburst cell was voltage clamped.

The second piece of evidence for a direct NMDA action on starburst cells emerged from a comparison of the noise charac- 

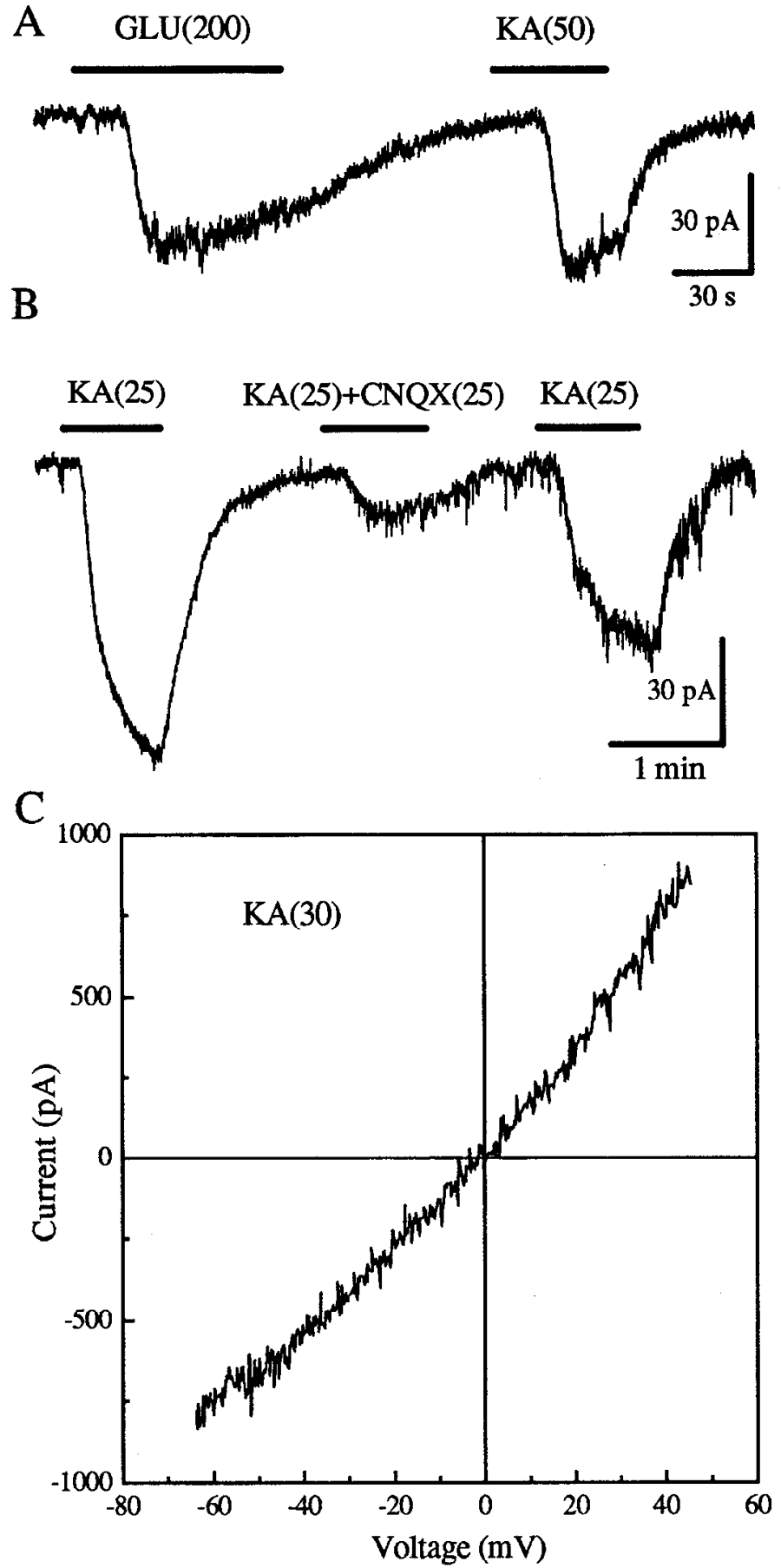

Figure 8. Responses of starburst cells to excitatory amino acids. A, The responses to bath-applied GLU $(200 \mu \mathrm{M}+1 \mu \mathrm{M}$ GLY $)$ and KA. $B$, Responses to KA were reversibly blocked by CNQX. $C$, The currentvoltage relation of $\mathrm{KA}$-evoked responses obtained from voltage-ramp experiments (see Materials and Methods), showing a nearly linear $I / V$ curve and a reversal potential close to the equilibrium potential for nonselective cations $\left(E_{\text {cat }}=6 \mathrm{mV}\right)$. Pipette solution P2, bath solution $\mathrm{B} 2+1 \mathrm{mM} \mathrm{Cd}^{2+}$ (see Table 1). Records in $A-C$ are all from different cells. Numbers shown in parentheses indicate the concentration of drug in $\mu \mathrm{M}$.

teristics of NMDA- and KA-evoked responses recorded from starburst cells in a $\mathrm{Cd}^{2+}$ - and $\mathrm{Mg}^{2+}$-free saline, supplemented with BIC $(200 \mu \mathrm{M})$, PTX $(200 \mu \mathrm{M})$, and STRYCH $(3 \mu \mathrm{M})$ to block inhibitory inputs. Under these conditions, responses in
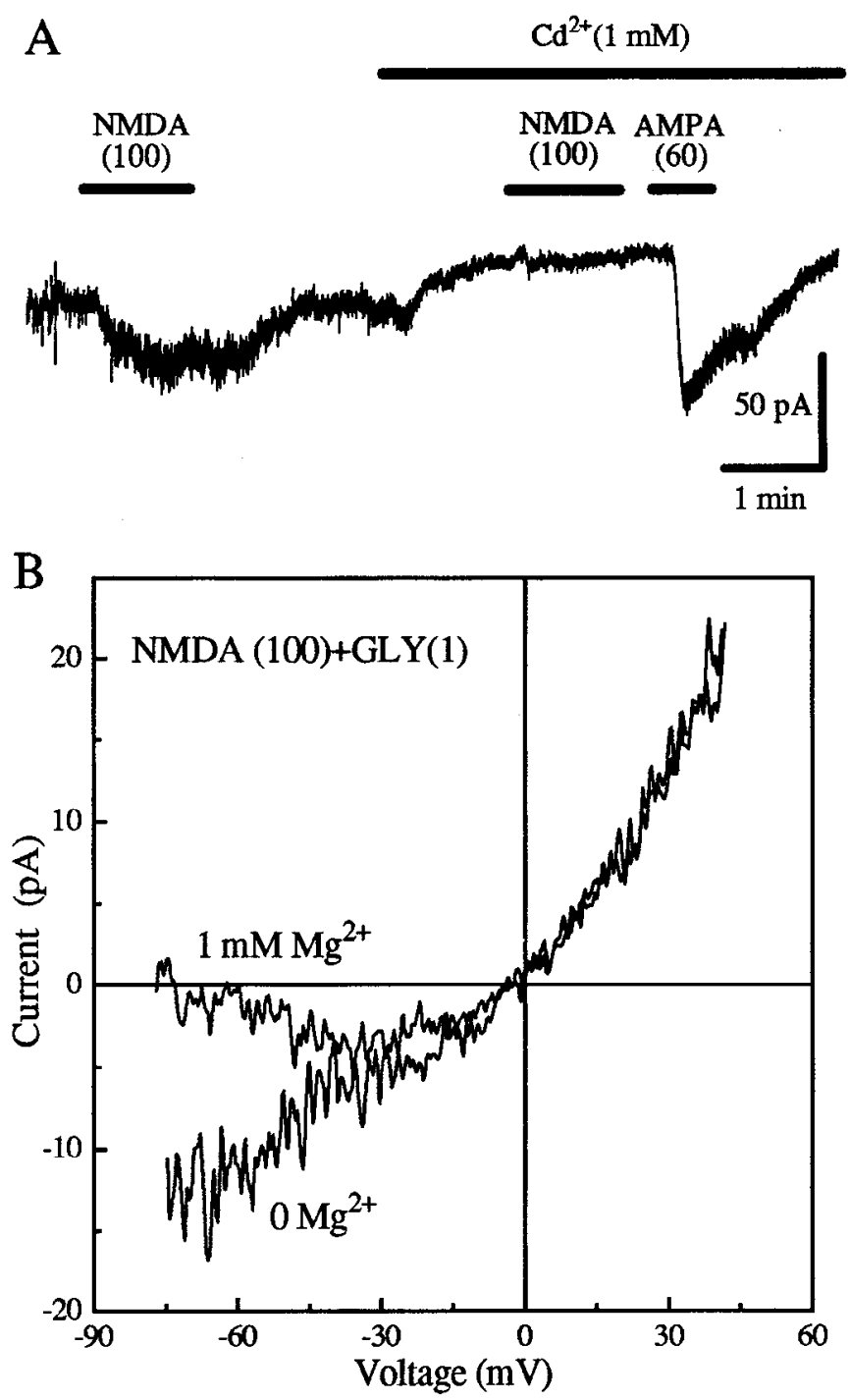

Figure 9. Responses of starburst cells to NMDA. A, Application of NMDA $\left(100 \mu \mathrm{M}\right.$, together with $1 \mu \mathrm{M}$ GLY) in the absence of $\mathrm{Mg}^{2+}$ and $\mathrm{Cd}^{2+}$ (bath solution $\mathrm{B} 2$, pipette solution P1) elicited an inward current from a starburst cell voltage clamped at $V_{h}=-70 \mathrm{mV}$. When $1 \mathrm{mM} \mathrm{Cd}^{2+}$ was added to the bath solution, the inward, background (holding) current became slightly smaller (seen in the figure as a small, upward shift of the holding current) and less noisy, and the cell no longer gave a response to NMDA $(100 \mu \mathrm{M}+1 \mu \mathrm{M}$ GLY $)$. Response to AMPA remained in the presence of $\mathrm{Cd}^{2+}, B$, Current-voltage relations of NMDA-evoked responses in another starburst cell. Whole-cell currents activated by NMDA plus GLY were recorded during voltage ramps first in a $\mathrm{Mg}^{2+}$-free $\left(0 \mathrm{Mg}^{2+}\right)$ saline (bath solution B3, pipette solution P2, see Table 1) and then in the same saline supplemented with $1 \mathrm{mM} \mathrm{Mg}^{2+}$. Numbers shown in parentheses indicate the concentration of drug in $\mu \mathrm{M}$.

starburst cells induced by KA and NMDA, either directly or indirectly (via interneurons), are most likely mediated by glutamate receptors on starburst cells, since fast responses to other major synaptic inputs were presumably blocked. If the starburst cell had no NMDA receptors, and its response to NMDA was mediated by interneurons, one would expect that KA- and NMDA-evoked responses in the starburst cell would have rather similar noise characteristics, since non-NMDA receptors are known to have smaller single channel conductances than NMDA receptors (Ascher and Nowak, 1988a; Ascher et al., 1988; CullCandy et al., 1988). On the other hand, should the starburst cell, 
A

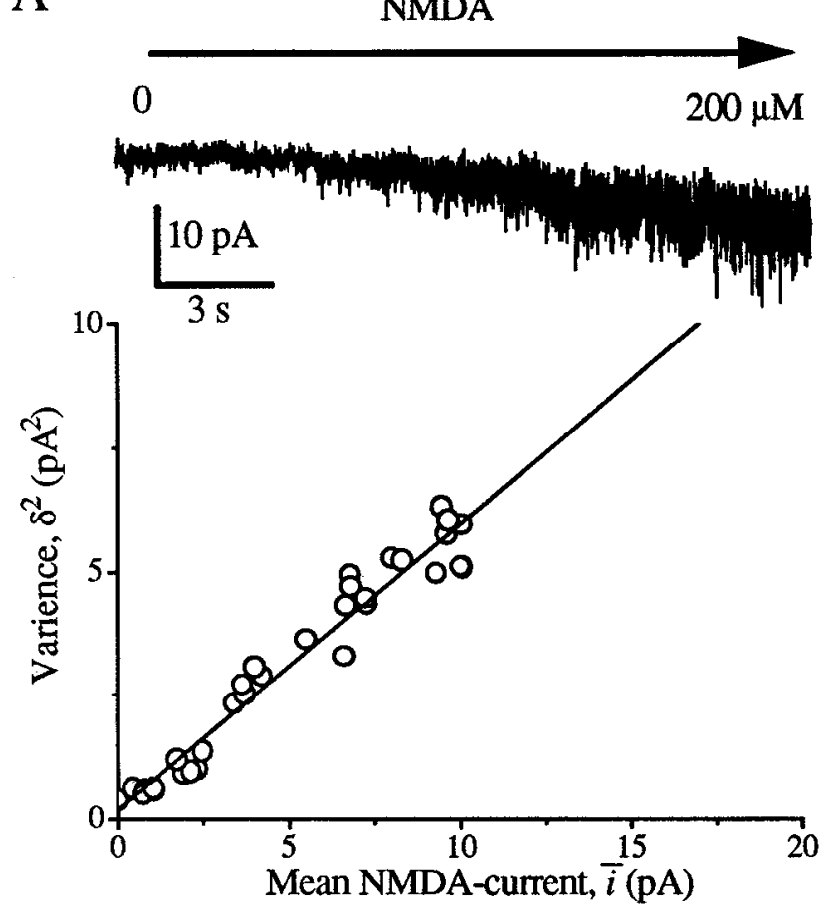

B

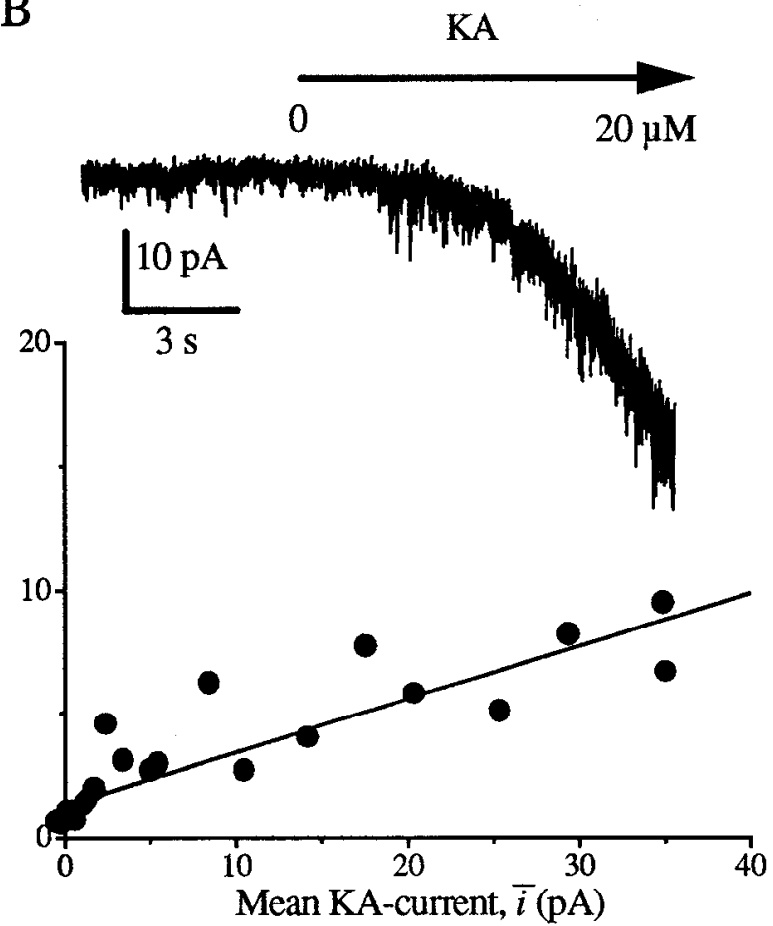

Figure 10. Comparison of the noise characteristics of NMDA- and KA-activated currents in a starburst cell. Responses of a cell to bath-applied NMDA $(200 \mu \mathrm{M}+1 \mu \mathrm{M}$ GLY, A, upper $)$ and $\mathrm{KA}(20 \mu \mathrm{M}, B$, upper $)$ were recorded under voltage clamp $\left(V_{h}=-70 \mathrm{mV}\right)$ in a $\mathrm{Mg}^{2+}-$ and $\mathrm{Cd}^{2+}-$ free saline (bath solution B3, pipette solution P2) supplemented with $200 \mu \mathrm{M}$ BIC, $200 \mu \mathrm{M}$ PTX, and $3 \mu \mathrm{M}$ STRYCH to block GABA receptors and glycine receptors. $A$. The current variance $\left(\delta^{2}\right)$ measured during the early part of the transition from control solution to $200 \mu \mathrm{M}$ NMDA was plotted as a function of the increase in mean inward current, $\bar{l} . B$, Variance versus mean current obtained during the initial transition from control solution to $20 \mu \mathrm{M}$ KA. Linear regression analysis (shown as straight lines) gave elementary conductance estimates of $\gamma_{\mathrm{NMDA}}=8.2 \mathrm{pS}$ and $\gamma_{\mathrm{KA}}=$ $3.1 \mathrm{pS}$ after division of the slopes by the driving force. Original current traces shown in the upper part of $A$ and $B$ were sampled at $1 \mathrm{kHz}$ (filtered at an $f_{c}$ of $300 \mathrm{~Hz}$, Butterworth filter). Data points shown in lower panels were derived from data sampled at $1.5 \mathrm{kHz}$ (see Materials and Methods).

indeed, possess NMDA receptors, one would anticipate that the noise characteristics of NMDA- and KA-induced responses in the starburst cell would be quite different.

Figure $10 \mathrm{~A}$ shows whole-cell current responses of a starburst cell to NMDA (100 $\mu \mathrm{M}$, coapplied with $1 \mu \mathrm{M}$ GLY) and KA $(20 \mu \mathrm{M})$. The response to NMDA in this cell consisted of a small net inward current accompanied by a large increase in noise. The elementary conductance estimated from the $\delta^{2}-\bar{l}$ plot (Fig. $10 \mathrm{~A}$ ) was $8.2 \mathrm{pS}$. From the same cell, however, the KA-evoked response consisted of a larger inward current with a smaller increase in noise. The estimated elementary conductance of the receptors mediating the KA response was $3.1 \mathrm{pS}$ (Fig. 10B). Thus, KA and NMDA appeared to have activated different receptor populations in the starburst cell, one dominated by nonNMDA receptors, and the other containing at least a proportion of NMDA receptors.

\section{Discussion}

Synaptic integration by starburst amacrine cells

By recording from identified displaced starburst amacrine cells under conditions in which synaptic transmission was blocked, we have directly demonstrated the presence of both excitatory and inhibitory amino acid receptors on these cells. Our results show that starburst cells receive direct GABAergic, glycinergic, and glutamatergic inputs, a finding that is consistent with anatomical observations that starburst cells are postsynaptic to cone bipolar cells and amacrine cells (Famiglietti, 1983b, 1991; Brandon, 1987).

GABA has been previously shown to inhibit the release of
ACh from the rabbit retina (Massey and Neal, 1979; Massey and Redburn, 1982; Cunningham and Neal, 1983), but the site of this inhibition has been unclear. It has been proposed, based on measurements of ACh release (Linn and Massey, 1992), that GABA acts indirectly on starburst cells via GABAergic feedback synapses on bipolar cell terminals. Our results, however, showed prominent $\mathrm{GABA}_{\mathrm{A}}$ receptors on starburst cells and thus provided the first convincing evidence for starburst cells being a direct, perhaps major, site of action for GABA to inhibit ACh release.

Since starburst cells provide a substantial cholinergic input to complex ganglion cells including direction-selective types (Masland and Ames, 1976; Ariel and Daw, 1982a; Amthor et al., 1988; Famiglietti, 1992), and since directional selectivity is blocked by the $\mathrm{GABA}_{\mathrm{A}}$ receptor antagonists, bicuculline and picrotoxinin (Wyatt and Daw, 1976), some implications for the mechanism of directional selectivity may be drawn from our results. First, the finding of $\mathrm{GABA}_{\mathrm{A}}$ receptors on starburst cells may provide a pharmacological basis for the concept that directional seiectivity results from GABA inhibition of ACh release, a mechanism proposed in some preganglionic models for directional selectivity (Masland et al., 1984b; Vaney, 1990; BorgGraham and Grzywacz, 1992). Although the existence of GABA receptors on starburst cells is by no means a sufficient proof of a role of starburst cells in mediating directional selectivity, the presence of GABA receptors is an essential requirement in the hypothesis that the starburst network, which appears to be in register with the dendritic loops of direction-selective ganglion 
cells (Amthor et al., 1989), may provide a direct substrate (i.e., site of action, Masland et al., 1984b) for the asymmetric GABAergic inhibition generally thought to be crucial for directional selectivity (Wyatt and Daw, 1976; Ariel and Daw, 1982b). It should be pointed out that models of this kind would have been effectively invalidated, if starburst cells had, indeed, lacked receptors for GABA (Linn and Massey, 1992).

The presence of $\mathrm{GABA}_{\mathrm{A}}$ receptors on starburst cells also raises another interesting possibility, that starburst cells may inhibit each other via GABAergic synapses, since these cells synapse onto each other (Brandon, 1987; Millar and Morgan, 1987; Famiglietti, 1991) and have been shown to synthesize, accumulate, and release GABA (Brecha et al., 1988; Kosaka et al., 1988; Vaney and Young, 1988; O'Malley and Masland, 1989). Given the extremely high degree of dendritic field overlap amongst starburst cells (Tauchi and Masland, 1984; Vaney, 1984; Famiglietti, 1985), the prospect of starburst cells using GABA to communicate with each other is particularly intriguing as a possible component in the network responsible for directional selectivity (Vaney, 1990). It is also possible that starburst cells use GABA $_{\mathrm{A}}$ receptors as autoreceptors in feedback networks. Apparently, GABA receptors constitute an important component of the starburst cell synaptic circuit, whose exact functional role will require further investigation.

\section{Glycine receptors}

Glycine also inhibits light-evoked ACh release by a strychninesensitive mechanism (Cunningham and Neal, 1983), but it has been doubtful whether starburst cells receive endogenous glycinergic input or whether they have strychnine-sensitive glycine receptors, becausc strychninc alone docs not have a consistent effect on basal or light-evoked release of ACh (Massey and Redburn, 1982; Cunningham et al., 1983; Neal and Cunningham, 1995). We now know from the present study that starburst cells do have strychnine-sensitive glycine receptors, and therefore it is most likely that they receive endogenous glycinergic input, presumably from glycinergic amacrine cells. However, it still remains to be determined how glycinergic inputs are arranged and why strychnine alone may show little effect on the release of $\mathrm{ACh}$ under certain experimental conditions. It has been suggested that an atropine-sensitive, baclofen-modulated (Neal and Cunningham, 1995) feedback loop may operate through glycinergic interneurons, but too little is known at present to predict the role of glycinergic input in the production of the light response of starburst cells.

\section{Excitatory amino acid receptors}

Our study has provided direct evidence for the coexistence of non-NMDA and NMDA receptors on starburst amacrine cells. This result may explain the finding that both KA and NMDA induce vigorous release of $\mathrm{ACh}$ from starburst cells (Cunningham and Neal, 1985; Linn and Massey, 1991; Linn et al., 1991). We found most starburst cells to give prominent responses to $\mathrm{KA}$ in the presence of $1 \mathrm{~mm} \mathrm{Cd}^{2+}$. The effect of NMDA was less robust and often quite small under our experimental conditions. Although NMDA receptors have been suggested not to mediate physiological input to starburst cells (Linn and Massey, 1991), we believe our evidence is sufficiently strong to postulate the existence of NMDA receptors on these cells. This conclusion is based on two pieces of evidence: the characteristic " $\mathrm{J}$ "shaped $I / V$ curve in the presence of $\mathrm{Mg}^{2+}$, and the differences in the noise characteristics of NMDA- and KA-evoked re- sponses. These two results are most easily explained by the presence of NMDA receptors directly on the starburst cell.

It should be noted that whereas the single channel conductance predicted for KA from our recordings (3.1 pS) is similar to that from noise measurements from other neurons in the CNS (0.15-3 pS, e.g., see Cull-Candy et al., 1988; Aschler and Nowak, 1988), that predicted for NMDA $(8.2 \mathrm{pS})$ is quite a bit smaller (22-47 pS, e.g., see Cull-Candy et al., 1988; Ascher and Nowak, 1988; Ascher et al., 1988). The most likely explanation for this discrepancy, in our opinion, is that the recordings for NMDA were done in a $\mathrm{Cd}^{2+}$-free bathing solution. It seems likely that the response to NMDA reflected both direct input from NMDA receptors and indirect input from other cells via nonNMDA receptors.

Occasionally, we recorded starburst cell responses to NMDA with a much less pronounced "J"-shaped region in the presence of $\mathrm{Mg}^{2+}$ than shown in Figure $9 B$, suggesting that in these cells a considerable part of the response to NMDA might have been indirect and have been mediated by NMDA receptors present on neurons presynaptic to starburst cells. Furthermore, in two starburst cells tested, responses to NMDA (200 $\mu \mathrm{M}$, coapplied with $2 \mu \mathrm{M}$ GLY) were partially blocked by CNQX $(25 \mu \mathrm{M})+$ PTX $(300 \mu \mathrm{M})+$ STRYCH $(4 \mu \mathrm{M})$, indicating an indirect action of NMDA on starburst cells, since the inhibitory effect of CNQX at the glycine-binding site of NMDA receptors is likely to be small in the presence of $2 \mu \mathrm{M}$ GLY (Birch et al., 1988; Neuman et al., 1988; Verdoorn et al., 1989; Thomson, 1990).

Since it is possible that application of NMDA in the absence of $\mathrm{Cd}^{2+}$ evoked both direct and indirect responses from starburst cells, and since the responses to NMDA were generally much smaller than those to KA, it remains to be determined to what extent NMDA receptors directly mediate the physiological excitatory input to starburst cells (Linn and Massey, 1991). On the other hand, it is also possible that the responses of starburst cells to bath-applied NMDA appeared small simply because the receptors were largely desensitized during the relatively slow application of drug. It is also possible that NMDA receptors contribute to modulation of starburst cell responses, for example, via $\mathrm{Ca}^{2+}$ influx through open NMDA channels.

In the vertebrate retinas so far examined, most first- and second-order neurons lack NMDA receptors (but see O'Dell and Christensen, 1989). Most, if not all ganglion cells, on the other hand, have been shown to possess NMDA receptors (Aizenman et al., 1988; Mittman et al., 1990; Yazejian and Fain, 1992; Cohen et al., 1994; Zhou et al., 1994). The distribution of NMDA receptors among amacrine cell types is presently unclear. $\Lambda$ II amacrine cells of the rat retina apparently lack NMDA receptors (Boos et al., 1993). In the salamander retina, transient amacrine cells have both NMDA and non-NMDA receptors, but sustained amacrine cells have only non-NMDA receptors (Dixon and Copenhagen, 1992). We show here that starburst cells, which give relatively transient responses to steps of light (Bloomfield, 1992), have NMDA receptors. Thus, the distribution of NMDA receptors among amacrine cells is likely to depend on cell type and perhaps species.

In a small number of starburst cells $(n=5)$, we tested the effects of 20-50 $\mu \mathrm{M} \mathrm{ACh}$ and carbachol, but no significant changes in the holding current were detected. In two of these cells a small increase in the noise of the holding current was seen during the application of $\mathrm{ACh}(30 \mu \mathrm{M})$. We have not tested any possible muscarinic effects in the present study.

Our study demonstrates that rabbit retinal slices provide a 
useful preparation for patch-clamp studies of starburst cell synaptic pharmacology and cellular physiology. It is our hope that this information will make it possible to produce more realistic models of synaptic integration for these cells, which may help us understand the nature of complex processing in the retina.

\section{References}

Aizenman E, Frosch MP, Lipton SA (1988) Responses mediated by excitatory amino acid receptors in isolated retinal ganglion cells from rat. J Physiol (Lond) 396:75-91.

Akaike N, Kaneda M (1989) Glycine-gated chloride currents in acutely isolated rat hypothalamic neurons. J Neurophysiol 62:1400-1408.

Ames A, Neshett FB (1981) In vitro retina as an experimental mode of the central nervous system. J Neurochem 37:867-877.

Amthor FR, Takahashi ES, Oyster CW (1989) Morphologies of rabbit retinal ganglion eclls with complex receptive fields. J Comp Neurol 280:97-121

Ariel M, Daw NW (1982) Pharmacological analysis of directionally sensitive rabbit retinal ganglion cells. J Physiol (Lond) 324:161-185.

Ascher P, Nowak L (1988a) Quisqualate- and kainate-activated channels in mouse central neurones in culture. J Physiol (Lond) 399:227245.

Ascher P, Nowak L (1988b) The role of divalent cations in the $\mathrm{N}$-methyl-D-aspartate responses of mouse central neurones in culture J Physiol (Lond) 399:247-266.

Ascher P, Bregestovski P, Nowark L (1988) $\mathrm{N}$-methyl-D-aspartate-activated channels of mouse central neurones in magnesium-free solutions. J Physiol (Lond) 399:207-226.

Birch PJ, Grossman CJ, Hayes AG (1988) 6,7-Dinitroquinoxaline-2,3dion and 6-nitro,7-cyanoquinoxaline-2,3-dion antagonise responses to NMDA in the rat spinal cord via an action at the strychnine-insensitive glycine receptor. Eur J Pharmacol 156:177-180

Bloomfield SA (1992) Relationship between receptive and dendritic field size of amacrine cells in the rabbit retina. J Neurophysiol 68 : $711-725$.

Bloomfield SA, Miller RF (1986) A functional organization of ON and OFF pathways in the rabbit retina. $J$ Neurosci $6: 1-13$.

Boos R, Schneider H, Wässle II (1993) Voltage- and transmitter-gated currents of AII-amacrine cells in a slice preparation of the rat retina. J Neurosci 13:2674-2888.

Borg-Graham LJ, Grzywacz NM (1992) A model of the directional selectivity circuit in the retina: transformations by neurons singly and in concert. In: Single neuron computation (McKenna T, Davis J, Zornetzer SF, eds), pp 347-375. New York: Academic.

Bormann J, Clapham DE (1985) $\gamma$-Aminobutyric acid receptor channels in adrenal chromaffin cells: a patch-clamp study. Proc Natl Acad Sci USA 82:2168-2172.

Bormann J, Hamill OP, Sakmann B (1987) Mechanism of anion permeation through channels gated by glycine and $\gamma$-aminobutyric acid in mouse cultured spinal neurons. J Physiol (Lond) 385:243-286.

Brandon C (1987) Cholinergic neurons in the rabbit retina: dendritic branching and ultrastructural connectivity. Brain Res 426:119-130.

Brecha N, John D, Peichl L, Wässle H (1988) Cholinergic amacrine cells of the rabbit retina contain glutamate decarboxylase and gammaaminobutyrate immunoreactivity. Proc Natl Acad Sci USA 85:61876191.

Cohen BN, Fain GL, Fain MJ (1989) GABA and glycine channels in isolated ganglion cells from the goldfish retina. J Physiol (Lond) 417: 53-82.

Cohen ED, Zhou ZJ, Fain GL (1994) Ligand-gated currents of alpha and beta ganglion cells in the cat retinal slice. J Neurophysiol 72 : $1260-1269$.

Cull-Candy SG, Ogden DC (1985) Ion channels activated by L-glutamate and GABA in cultured cerebellar neurons of the rat. Proc $\mathrm{R}$ Soc Lond [Biol] 224:367-373.

Cull-Candy SG, Howe JR, Ogden DC (1988) Noise and single channels activated by excitatory amino acids in rat cerebellar granule neurons. J Physiol (Lond) 400:189-222.

Cunningham JR, Neal MJ (1983) Effect of $\gamma$-aminobutyric acid agonists, glycine, taurine and neuropeptides on acetylcholine release from the rabbit retina. J Pliysiol (Lond) 336:455-468.

Cunningham JR, Neal MJ (1985) Effects of excitatory amino acids and analogues on ${ }^{3} \mathrm{H}$-acetylcholine release from amacrine cells of the rabbit retina. J Physiol (Lond) 366:47-62.
Cunningham JR, Dawson C, Neal M.I (1983) Evidence for a cholinergic inhibitory feed-back mechanism in the rabbit retina. J Physiol (Lond) 340:455-468.

Dixon DB, Copenhagen DR (1992) Two types of glutamate receptors differentially excite amacrine cells in the tiger salamander retina. J Physiol (Lond) 449:589-606.

Dong C-J, Picaud SA, Werblin FS (1994) GABA transporters and GA$\mathrm{BA}-$-like receptors on catfish cone- but not rod-driven horizontal cells. J Neurosci 14:2648-2658.

Dowling JE (1970) Organization of vertebrate retinas. Invest Ophthalmol 9:655-680.

Dowling JE (1987) The retina: an approachable part of the brain, pp 113-1 16. Cambridge, MA: Belknap (Harvard UP)

Edwards FA, Konnerth A, Sakmann B, Takahashi T (1989) A thin slice preparation for patch clamp recordings from neurones of the mammalian central nervous system. Pfluegers Arch 414:600-612.

Fain GL, Zhou ZJ (1993) Patch-clamp recordings from DAPI-labeled starburst amacrine cells in a rabbit retinal slice preparation. Soc Neurosci Abstr 19:230.

Famiglietti EV (1983a) 'Starburst' amacrine cells and cholinergic neurons: mirror-symmetric $\mathrm{ON}$ and $\mathrm{OFF}$ amacrine cells of rabbit retina. Brain Res 261:138-144.

Famiglietti EV (1983b) On and Off pathways through amacrine cells in mammalian retina: the synaptic connectivity of 'Starburst' amacrine cells. Vision Res 23:1265-1279.

Famiglietti EV (1985) Starburst amacrine cells: morphological consistency and systematic variation in the anisotropic field of rabbit retinal neurons. J Neurosci 5:562-577.

Famiglietti ED (1991) Synaptic organization of starburst amacrine cells in rabbit retina: analysis of serial thin sections by electron microscopy and graphic reconstruction. J Comp Neurol 309:40-70.

Famiglietti EV (1992) Dendritic co-stratification of ON and ON-OFF directionally selective ganglion cells with starburst amacrine cells in rabbit retina. J Comp Neurol 324:322-335.

Feigenspan A, Wässle H, Bormann J (1993) Pharmacology of GABA receptor $\mathrm{Cl}$ channels in rat retinal bipolar cells. Nature 361:159-162.

Fenwick EM, Marty A, Neher E (1982) A patch-clamp study of bovine chromaffin cells and of their sensitivity to acetylcholine. J Physiol (Lond) 331:577-597.

Ffrench-Constant RH, Rocheleau TA, Steichen JC, Chalmers AE (1993) A point mutation in a Drosophila GABA receptor confers insecticide resistance. Nature 363:449 451.

Hamill OP, Bormann J, Sakmann B (1983) Activation of multipleconductance state chloride channels in spinal neurons by glycine and GABA. Nature 305:805-808.

Ineaga K, Mason WT (1987) $\gamma$-Aminobutyric acid modulates chloride channel activity in cultured primary bovine lactorphs. Neuroscience 23:649-660.

Ishida AT, Cohen BN (1988) GABA-activated whole-cell currents in isolated retinal ganglion cells. J Neurophysiol 60:381-396.

Johnston D, Wu SM-S (1995) Foundation of cellular neurophysiology, pp 1222-1224. Cambridge, MA: MIT Press.

Johnston GA, Curtis DR, Beart PM, Game CJ, McCulloch RM, Twitchin B (1975) Cis- and trans-4-aminocrotonic acid as GABA analogues of restricted conformation. J Neurochem 24:157-160.

Kosaka T, Tauchi M, Dahl JL (1988) Cholinergic neurons containing GABA-like and/or glutamic acid decarboxylase-like immunoreactivities in various brain regions of the rat. Exp Brain Res 70:605-617.

Linn DM, Massey SC (1991) Acetylcholine release from the rabbit retina mediated by NMDA receptors. J Neurosci 11:123-133.

Linn DM, Massey SC (1992) GABA inhibits $\Lambda$ Ch release from the rabbit retina: a direct effect or feedback to bipolar cells? Vis Neurosci 8:97-106.

Linn DM, Christine B, Redburn DA, Massey SC (1991) Acetylcholine release from the rabbit retina mediated by kainate receptors. J Neurosci 11:111-122.

Lukasiewicz PD, Maple BR, Werblin FS (1994) A novel GABA receptor on bipolar cell terminals in the tiger salamander retina. J Neurosci 14:1202-1212.

MacDonald RL, Rogers CJ, Twyman RE (1989) Kinetic properties of the $\mathrm{GABA}_{\mathrm{A}}$ receptor main conductance state of mouse spinal cord neurones in culture. J Physiol (Lond) 410:479-490.

Maguire G, Lukasiewicz PD, Werblin FS (1989a) Amacrine cell interactions underlying the response to change in the tiger salamander retina. J Neurosci 9:726-735. 
Maguire G, Maple B, Lukasiewicz P, Werblin F (1989b) $\gamma$-Aminobutyrate type $B$ receptor modulation of L-type calcium channel current at bipolar cell terminals in the retina of tiger salamander. Proc Natl Acad Sci USA 86:10144-10147.

Marty A, Neher E (1983) In: Single-channel recordings (Sakmann B, Neher E, eds), pp 107-122. New York: Plenum.

Masland RH, Ames A III (1976) Responses to ACh of ganglion cells in an isolated mammalian retina. J Neurophysiol 39:1220-1235.

Masland RH, Tauchi M (1986) The cholinergic amacrine cells. Trends Neurosci 9:218-223.

Masland RH, Mills JW, Hayden SA (1984a) Acetylcholine-synthesizing amacrine cells: identification and selective staining by using radioautography and fluorescent markers. Proc R Soc Lond [Biol] 223: $79-100$.

Masland RH, Mills JW, Cassidy C (1984b) The functions of acetylcholine in the rabbit retina. Proc R Soc Lond [Biol] 223:121-139.

Massey SC, Neal MJ (1979) The light-evoked release of acetylcholine from the rabbit retina in vivo and its inhibition by gamma-aminobutyric acid. J Neurochem 32:1327-1329.

Massey SC, Redburn DA (1982) A tonic $\gamma$-aminobutyric acid-mediated inhibition of cholinergic amacrine cells in rabbit retina. $\mathrm{J}$ Neurosci 2:1633-1643.

Massey SC, Redburn DA (1987) Transmitter circuits in the vertebrate retina. Prog Neurobiol 28:55-96.

Matthews G, Ayoub GS, Heidelberger R (1994) Presynaptic inhibition by GABA is mediated via two distinct GABA receptors with novel pharmacology. J Ncurosci 14:1079-1090.

Mayer ML, Westbrook GL (1987) Permeation and block of $N$-methylD-aspartic acid receptor channels by divalent cations in mouse cultured central neurones. J Physiol (Lond) 394:501-527.

Mayer ML, Westbrook GL, Guthrie PB (1984) Voltage-dependent block by $\mathrm{Mg}^{2+}$ of NMDA responses in spinal cord neurones. Nature 309:261-263.

Mayer ML, Vyklicky L, Westbrook GL (1989) Modulation of excitatory amino acid receptors by group IIB metal cations in cultured mouse hippocampal neurones. J Physiol (Lond) 415:329-350.

Millar TJ, Morgan IG (1987) Cholinergic amacrine cells in the rabbit retina synapse onto other cholinergic amacrine cells. Neurosci Lett 74:281-285.

Mittman S, Taylor WR, Copenhagen DR (1990) Concomitant activation of two types of glutamate receptor mediates excitation of salamander retinal ganglion cells. J Physiol (Lond) 428:175-197.

Neal MJ, Cunningham JR (1995) Baclofen enhancement of acetylcholine release from amacrine cells in the rabbit retina by reduction of glycinergic inhibition. J Physiol (Lond) 482:363-372.

Neher E, Stevens CF (1977) Conductance fluctuations and ionic pores in membranes. Annu Rev Biophys Bioeng 6:345-381.

Neuman RS, Ben-Ari Y, Gho M, Cherubini E (1988) Blockade of excitatory synaptic transmission by 6-cyano-7-nitroquinoxaline-2,3dion (CNQX) in the hippocampus in vitro. Neurosci Lett 92:64-68.

Nowak L, Bregestovski P, Ascher P, Herbet A, Prochiantz A (1984) Magnesium gates glutamate-activated channels in mouse central neurones. Nature 307:462-465.

O'Dell TJ, Christensen BN (1989) Horizontal cells from catfish retina contain two types of excitatory amino acid receptors. J Neurophysiol 61:1097-1109.

O'Malley DM, Masland RH (1989) Co-release of acetylcholine and gamma-aminobutyric acid by a retinal neuron. Proc Natl Acad Sci USA 85:8737-8741.

Pan ZH, Slaughter MM (1991) Control of retinal information coding by $\mathrm{GABA}_{\mathrm{B}}$ receptors. J Neurosci 11:1810-1821.

Qian H, Dowling JE (1993) Novel GABA responses from rod-driven retinal horizontal cells. Nature 361:162-164.

Slaughter MM, Bai S-H (1989) Differential effects of baclofen on sustained and transient cells in the mudpuppy retina. J Neurophysiol 61: 373-381.

Tauchi M, Masland RH (1984) The shape and arrangement of the cholinergic neurons in the rabbit retina. Proc R Soc Lond [Biol] 223: 101-119.

Tauchi M, Masland RH (1985) Local order among the dendrites of an amacrine cell population. J Neurosci 5:2495-2501.

Thomson AM (1990) Glycine is a coagonist at the NMDA receptor/ channel complex. Prog Neurobiol 35:53-74.

Ticku MK, Van Ness PC, Haycock JW, Levy WB, Olsen RW (1978) Dihydropicrotoxinin binding sites in rat brain: comparison to GABA receptors. Brain Res 150:642-647.

Vaney DI (1984) 'Coronate' amacrine cells in the rabbit retina have the 'starburst' dendritic morphology. Proc R Soc Lond [Biol] 220: 501-508.

Vaney DI (1990) The mosaic of amacrine cells in the mammalian retina. Prog Ret Res 9:49-100.

Vaney DI, Young HM (1988) GABA-like immunoreactivity in cholinergic amacrine cells of the rabbit retina. Brain Res 438:369-373.

Verdoorn TA, Kleckner NW, Dingledine R (1989) N-methyl-D-aspartate/glycine and quisqualate/Kainate receptors expressed in Xenopus oocytes: antagonist pharmacology. Mol Pharmacol 35:360-368.

Wässle H, Boycott BH (1991) Functional architecture of the mammalian retina. Physiol Rev 2:447-480.

Werblin FS (1978) Transmission along and between rods of the tiger salamander relina. J Physiol (Lond) 280:449-470.

Wu SM-S (1987) Synaptic connections between neurons in living slices of the larval tiger salamander retina. J Neurosci Methods 20:139149.

Wyatt HJ, Daw NW (1976) Specific effects of neurotransmitter antagonists on ganglion cells in rabbit retina. Science 191:204-205.

Yazejian B, Fain GL (1992) Excitatory amino acid receptors on isolated retinal ganglion cells from the goldfish. J Neurophysiol 67:94107.

Yazulla S (1986) GABAergic mechanisms in the retina. Prog Ret Res 5:1-52.

Zhou ZJ, Fain GL (1994) Synaptic receptor pharmacology of starburst amacrine cells in rabbit retinal slices. Invest Ophthalmol Vis Sci [Suppl] 35:2057.

Zhou ZJ, Fain GL, Dowling JE (1993) The excitatory and inhibitory amino acid receptors on horizontal cells isolated from the white perch retina. J Neurophysiol 70:8-19.

Zhou ZJ, Marshak DW, Fain GL (1994) Amino acid receptors of midget and parasol ganglion cells in primate retina. Proc Natl Acad Sci USA 91:4907-4911. 